University of New Hampshire

University of New Hampshire Scholars' Repository

$5-1-1997$

\title{
Continental scale variability in ecosystem processes: Models, data, and the role of disturbance
}

David S. Schimel

NCAR

Rob Braswell

University of New Hampshire - Main Campus, rob.braswell@unh.edu

Follow this and additional works at: https://scholars.unh.edu/earthsci_facpub

\section{Recommended Citation}

Schimel, D. S., Participants, V. and Braswell, B. H. (1997), CONTINENTAL SCALE VARIABILITY IN ECOSYSTEM PROCESSES: MODELS, DATA, AND THE ROLE OF DISTURBANCE. Ecological Monographs, 67: 251-271. doi:10.1890/0012-9615(1997)067[0251:CSVIEP]2.0.CO;2

This Article is brought to you for free and open access by the Earth Sciences at University of New Hampshire Scholars' Repository. It has been accepted for inclusion in Earth Sciences Scholarship by an authorized administrator of University of New Hampshire Scholars' Repository. For more information, please contact Scholarly.Communication@unh.edu. 


\title{
CONTINENTAL SCALE VARIABILITY IN ECOSYSTEM PROCESSES: MODELS, DATA, AND THE ROLE OF DISTURBANCE
}

\author{
David S. Schimel, ${ }^{1}$ VEMAP Participants, ${ }^{2}$ AND B. H. Braswell ${ }^{3}$ \\ ${ }^{1}$ National Center for Atmospheric Research, P.O. Box 3000, Boulder, Colorado 80307-3000 USA and Natural Resources \\ Ecology Laboratory, Colorado State University, Fort Collins, Colorado 80523 USA \\ ${ }^{2}$ Department of Environmental Sciences, University of Virginia, Charlottesville, Virginia 22903 USA: W. Emanuel, B. \\ Rizzo, T. Smith; Department of Plant and Animal Sciences, University of Sheffield, P.O. Box 601, Sheffield S10 2UQ, UK: \\ F. I. Woodward; National Center for Atmospheric Research, P.O. Box 3000, Boulder, Colorado 80307-3000 USA: H. \\ Fisher, T. G. F. Kittel, R. McKeown, T. Painter ${ }^{4}$, N. Rosenbloom; Natural Resources Ecology Laboratory, Colorado State \\ University, Fort Collins, Colorado 80523 USA: D. S. Ojima, W. J. Parton; The Ecosystems Center, Marine Biological \\ Laboratory, Woods Hole, Massachusetts 02543 USA: D. W. Kicklighter, A. D. McGuire, J. M. Melillo, Y. Pan; University \\ of Lund, östra Vallsatian 14, 22361 Lund, Sweden: A. Haxeltine, C. Prentice, S. Sitch; University of Montana, Missoula, \\ Montana 59812 USA: K. Hibbard, R. Nemani, L. Pierce, S. Running; USDA Forest Service, Oregon State University, 3200 \\ SW Jefferson Way, Corvallis, Oregon 97333 USA: J. Borchers, J. Chaney, R. Neilson (institutions are listed alphabetically, \\ participants are alphabetized within group) \\ ${ }^{3}$ Institute for Earth Oceans and Space, The University of New Hampshire, Durham, New Hampshire 03824 USA and \\ National Center for Atmospheric Research, Boulder, Colorado 80307-3000 USA
}

\begin{abstract}
Management of ecosystems at large regional or continental scales and determination of the vulnerability of ecosystems to large-scale changes in climate or atmospheric chemistry require understanding how ecosystem processes are governed at large spatial scales. A collaborative project, the Vegetation and Ecosystem Modeling and Analysis Project (VEMAP), addressed modeling of multiple resource limitation at the scale of the conterminous United States, and the responses of ecosystems to environmental change. In this paper, we evaluate the model-generated patterns of spatial variability within and between ecosystems using Century, TEM, and Biome-BGC, and the relationships between modeled water balance, nutrients, and carbon dynamics. We present evaluations of models against mapped and site-specific data. In this analysis, we compare model-generated patterns of variability in net primary productivity (NPP) and soil organic carbon (SOC) to, respectively, a satellite proxy and mapped SOC from the VEMAP soils database (derived from USDA-NRCS [Natural Resources Conservation Service] information) and also compare modeled results to site-specific data from forests and grasslands. The VEMAP models simulated spatial variability in ecosystem processes in substantially different ways, reflecting the models' differing implementations of multiple resource limitation of NPP. The models had substantially higher correlations across vegetation types compared to within vegetation types. All three models showed correlation among water use, nitrogen availability, and primary production, indicating that water and nutrient limitations of NPP were equilibrated with each other at steady state. This model result may explain a number of seemingly contradictory observations and provides a series of testable predictions. The VEMAP ecosystem models were implicitly or explicitly sensitive to disturbance in their simulation of NPP and carbon storage. Knowledge of the effects of disturbance (human and natural) and spatial data describing disturbance regimes are needed for spatial modeling of ecosystems. Improved consideration of disturbance is a key "next step" for spatial ecosystem models.
\end{abstract}

Key words: disturbance; evapotranspiration; model comparison and validation; nitrogen mineralization; NPP; remote sensing; soil carbon.

\section{INTRODUCTION}

A central challenge for ecology is to understand how ecosystem processes are governed at large spatial scales. A recent study, the Vegetation and Ecosystem Modeling and Analysis Project (VEMAP), addressed

Manuscript received 4 December 1995; revised 12 June 1996; accepted 30 June 1996; final version received 26 July 1996.

${ }^{4}$ Present address: Department of Geography, University of California, Santa Barbara, California 93107 USA. the response of biogeography and biogeochemistry to environmental variability in climate and soils in both the space and time domains. VEMAP has as its objectives the intercomparison of biogeochemistry models and vegetation type distribution models (biogeography models), and the determination of sensitivity of these models to changing climate and atmospheric carbon dioxide concentrations. The project's domain was the conterminous United States, using a $0.5^{\circ}$ grid. The project was structured as a sensitivity analysis, with factorial combinations of climate (current and in response 


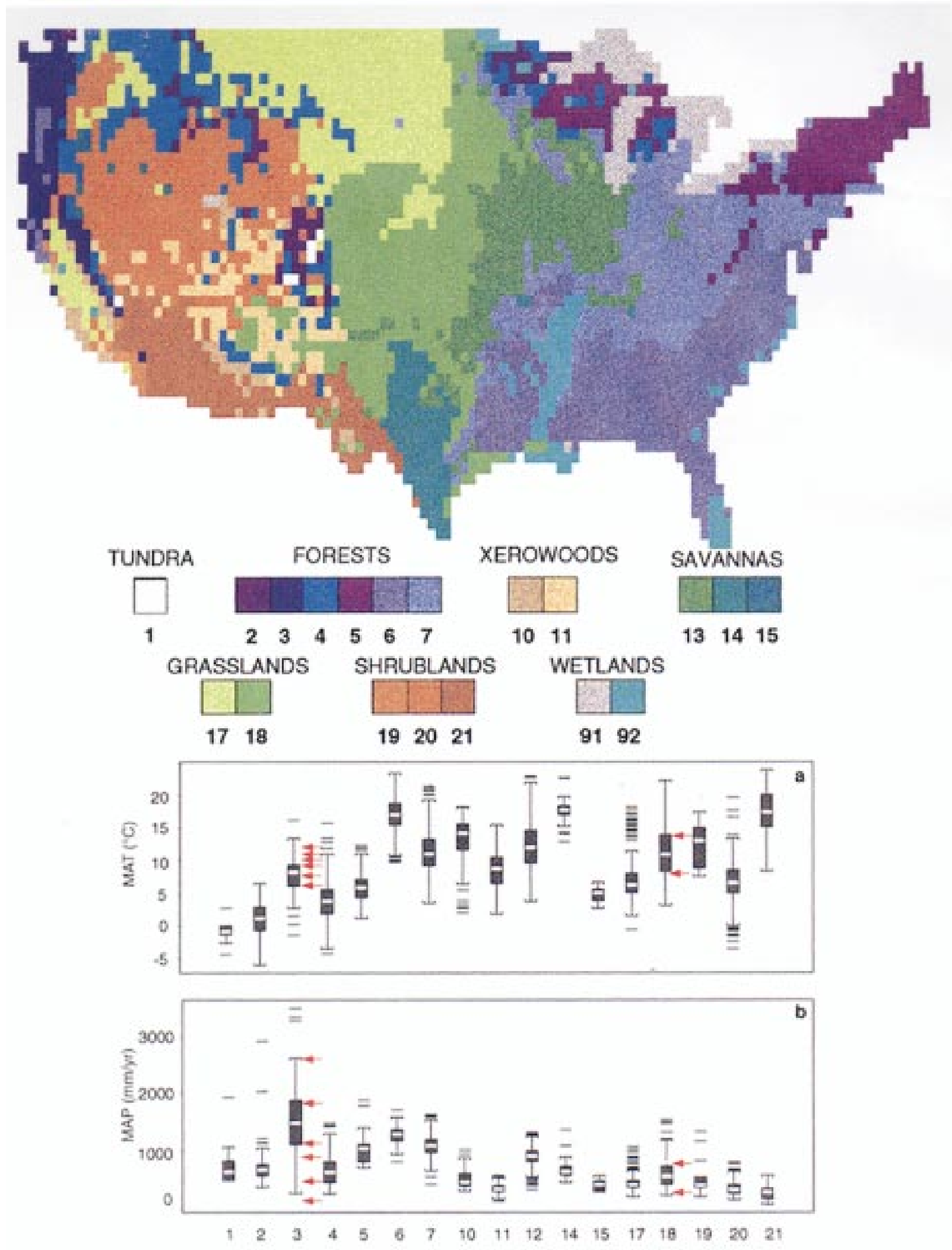


$\leftarrow$

Fig. 1. Map of the vegetation classes used in VEMAP (see Table 1 for additional description). "Xerowoods" indicates the xeromorphic woodland category. Wetland classes were not included in model calculations.

to projected doubled $\mathrm{CO}_{2}$ ), atmospheric $\mathrm{CO}_{2}$, and mapped and model-generated vegetation distributions. Maps of climate, climate change scenarios, soil properties, and potential natural vegetation were prepared as common inputs to the models (Kittel et al. 1995) to allow for rigorous intercomparison. VEMAP (1995) compared the models' spatially aggregated responses in the simulation of contemporary conditions and sensitivity to change. That paper also drew preliminary conclusions regarding links between the model-specific responses in the sensitivity analysis and the mechanisms and parameter values employed in those models. Initial analyses from VEMAP suggested that modelspecific differences in sensitivity to changes in physical variables vs. internal nutrient limitations caused differences in modeled sensitivity to climate change (VEMAP 1995). This paper extends that analysis using spatial variability along environmental gradients under the current climate to better understand the complex responses of the VEMAP biogeochemistry models to the physical environment and nutrient cycling.

Because many environmental changes imply changes to environmental resources through changing climate, atmospheric nutrient deposition, and species composition, understanding the interactions of environmental resources is a precondition for credible predictive modeling (Ehleringer and Field 1993). Environmental resources (light, water, nutrients) and plant attributes (e.g., carbon and nitrogen status and allocation, tissue chemistry) are linked to production and decomposition (Farqhuar et al. 1980, Melillo et al. 1984, Bloom et al. 1985, Chapin et al. 1987, Nobel 1991, Running and Nemani 1991). The concepts of multiple resource limitation have been explored in theoretical and empirical studies (Thornley 1972, Bloom et al. 1985, Tilman 1985, Ingestad and Lund 1986, Chapin et al. 1987, Field 1991, Schimel et al. 1991). Joint limitation by carbon dioxide, water, light, and nitrogen affects plant growth, allocation patterns, nutrient cycling, and competition (Christie and Detling 1982, Eisele et al. 1989, Wedin and Tilman 1990, Schimel et al. 1991).

Spatial models based on multiple resource limitation require information describing spatial-temporal patterns of resource distribution and availability. Early efforts to link ecological responses to environmental gradients included only variables related to temperature and precipitation (e.g., Holdridge 1967, Lieth 1972, Esser 1986). Current spatial models of productivity, carbon storage, and nutrient cycling, "biogeochemistry models," use additional information on climate (radiation, humidity, and other sources) and soil properties, and include vegetation type-specific parameters (Burke et al. 1991, Burke and Lauenroth 1993, McGuire et al. 1993, Running and Hunt 1993, Schimel et al. 1994, VEMAP 1995). These models simulate the components of spatial variability in ecosystem processes governed by climate, soil, and vegetation type. As a result they use, and require, maps of these variables as input (Kittel et al. 1995).

The biogeochemistry models employed in VEMAP all include multiple environmental resources (water, light, nutrients) as controls over plant and ecosystem processes, although with quite different approaches (TEM: McGuire et al. 1993; Biome-BGC: Running and Hunt 1993; Century: Parton et al. 1994, Schimel et al. 1994). VEMAP (1995) identified differences in representation of multiple resource limitation as one of the most important factors controlling the models' aggregate responses to environmental change. The interaction of the spatial distribution of environmental resources, or controls over resource availability (e.g., soil properties), with model-specific mechanisms will influence spatial patterns of ecosystem response to multiple environmental resources and stresses.

This paper is a follow on and expansion of the VEMAP (1995) work, analyzing the responses of the biogeochemistry models under current climate and current $\mathrm{CO}_{2}$ concentrations. The objectives of this paper were twofold: to utilize spatial variability in model responses to diagnose the importance of different underlying mechanisms, and to explore methodology and data sets for evaluating simulated spatial variability relative to observations. For the first objective we utilized the spatial gradients of environmental resources within the VEMAP domain to quantify differences in sensitivity to climatic vs. biogeochemical processes between the models. Such differences in sensitivity were hypothesized to result in the different responses to altered climate and $\mathrm{CO}_{2}$ among TEM, Century, and BiomeBGC (VEMAP 1995); this paper provides quantitative evaluation of intermodel differences. Second, we explored a variety of approaches to testing the fidelity of

$\leftarrow$

Fig. 2. Box-plots for (a) mean annual temperature and (b) mean annual precipitation. The white bar within each box marks the mean value, the upper and lower edges of the box mark the first and third quartiles, the upper and lower brackets denote the 95th and 5th percentiles, and the black dashes indicate outliers for each vegetation type. Red arrows on Fig. 2a and $b$ indicate the mean annual temperature and precipitation of OTTER experiment sites within the maritime coniferous vegetation type (Runyon et al. 1994), and of the Konza and CPER LTER sites within the $\mathrm{C}_{4}$ grasslands. 
simulated spatial variability, including comparisons to mapped soils data, remote observations, and site data along environmental gradients within ecosystems. Testing of spatial ecosystem models has focused on comparisons at limited numbers of specific experimental sites, often unreplicated within broad vegetation classes, and this is clearly inadequate for comprehensive model evaluation.

\section{METHODS}

\section{Vegetation types and associated climates}

Fig. 1 shows the mapped potential natural vegetation used in VEMAP to calibrate vegetation distribution models (not discussed in this paper) and to prescribe vegetation type-specific parameters for the biogeochemistry models. The vegetation types included are aggregated from the map of Küchler (1964) and are described briefly in Table 1. Because the biogeochemistry models have vegetation type-specific parameters, the classification scheme is intertwined with the model conceptualizations employed (VEMAP 1995). The aggregation scheme represents a compromise compatible with all of the models, although they use the scheme in different ways. For example, Biome-BGC lumps the 17 categories present under current climate into six distinct parameterizations (Table 1). All three models treat some categories as mixtures of fundamental categories (e.g., all three models treat the temperate deciduous savanna as a grassland/forest mixture). The life-form combinations used by each model for each vegetation type are listed in Table 1.

The models used climate information developed for the VEMAP project (Kittel et al. 1995) based on longterm station data for the United States. The climate data included monthly (used in Century and TEM), and daily (used in BGC) resolution versions. The monthly version was interpolated from a large database to the VEMAP grid (NCDC 1992). Daily variance in temperature and precipitation was modeled using a statistical weather generator based on the more limited daily climate records available (Eddy 1987), constrained to have the same monthly means as the monthly version (Richardson and Wright 1984). The procedures for developing the multiple time-scale climate data are described in Kittel et al. (1995). The temperature data were adjusted for elevation using adiabatic lapse rates. The precipitation data were adjusted for elevation and topography using the PRISM model (Daly et al. 1994), a routine that divides the terrain into facets with similar aspect, and develops precipitation-elevation regressions for each facet by region from stratified station data. These regional regressions are then used to estimate precipitation by extrapolating station precipitation to unsampled cells with similar facets. The PRISM calculations were carried out on a $10-\mathrm{km}$ grid and aggregated to the VEMAP grid.

The adjustment of climate data to realistic topog- raphy is a crucial step in allowing comparison of modeled data with observations. Typical climatologies do not account for orographic (e.g., rain shadow) and elevational effects except to the extent that they are captured in station distributions and so may be considerably in error for high relief or sparsely sampled areas. When such data are used as model input, simulations in regions of complex terrain are likely to produce unrealistic ecological responses because ecological processes are indeed sensitive to the magnitude of variations in temperature and precipitation induced by orography (Whittaker 1975). The development of realistic climate data is not strictly required in comparative or sensitivity studies, but is a necessary precondition if validation is to be attempted, and was also required to allow the VEMAP biogeography models to simulate current vegetation distributions matched to mapped observations. Fig. $2 \mathrm{a}$ and $\mathrm{b}$ show the mean annual climate characteristics of the VEMAP vegetation classes. Many vegetation types overlap in this simplified climate space, some nearly completely. The actual climates of the vegetation types differ more than is evident in Fig. $2 \mathrm{a}$ and $\mathrm{b}$ due to patterns of seasonality, and the effects of humidity, wind, and solar radiation.

\section{Model descriptions}

The three biogeochemistry models considered in this paper (Biome-BGC, Century, and TEM) simulate the cycles of carbon, nitrogen, and water in terrestrial ecosystems (McGuire et al. 1993, Running and Hunt 1993, Parton et al. 1994). An overview of model characteristics is shown in Table 2, and more detailed information is available in VEMAP (1995). The models employ general frameworks for all vegetation types, but have some parameters or functions that vary by vegetation type. Examples of such vegetation type-specific relationships include the fractional allocation to type of plant tissue (e.g., no wood specified in grasslands) and carbon-to-nitrogen ratios. The models simulate evapotranspiration (ET), photosynthesis and/or net primary production, decomposition, and soil nitrogen turnover as influenced by climate variables and soil properties. The models represent the structure of ecosystems with different degrees of aggregation (see Table 2), but all can produce estimates of net primary productivity (NPP), net nitrogen mineralization, evapotranspiration, and carbon storage for living (vegetation carbon), nonliving (soil carbon including carbon in detritus), and total ecosystem (living plus nonliving) compartments.

The goal of VEMAP was to compare steady-state results and sensitivities: each model approximated this condition differently. TEM is designed to compute steady-state conditions, and was run until equilibrium was achieved (net ecosystem production $(\mathrm{NEP})=0.0$ ). Conditions in TEM reflected the ages of the calibration systems used for each distinct vegetation type (Table 2). Biome-BGC was initialized for near steady-state 
TABLE 1. Description of the potential natural vegetation classes employed in VEMAP.

\begin{tabular}{|c|c|c|c|c|}
\hline $\begin{array}{l}\text { Vege- } \\
\text { tation } \\
\text { class }\end{array}$ & Vegetation description & Biome-BGC & Century & TEM \\
\hline 1 & Tundra & $\mathrm{C}_{3}$ grassland & Tundra & Alpine tundra \\
\hline 2 & Boreal coniferous forest & Coniferous forest & Subalpine fir: $100-y r$ burn & Boreal coniferous forest \\
\hline 3 & $\begin{array}{l}\text { Temperate maritime co- } \\
\text { niferous forest }\end{array}$ & Coniferous forest & $\begin{array}{l}\text { Western pine: } 500-y r \\
\text { burn }\end{array}$ & $\begin{array}{l}\text { Maritime temperate conif- } \\
\text { erous forest }\end{array}$ \\
\hline 4 & $\begin{array}{l}\text { Temperate continental co- } \\
\text { niferous forest }\end{array}$ & Coniferous forest & $\begin{array}{l}\text { Western pine: } 100-y r \\
\text { burn }\end{array}$ & $\begin{array}{l}\text { Continental temperate co- } \\
\text { niferous forest }\end{array}$ \\
\hline 5 & $\begin{array}{l}\text { Cool temperate mixed } \\
\text { forest }\end{array}$ & $\begin{array}{l}50 \% \text { coniferous forest, } \\
50 \% \text { deciduous forest }\end{array}$ & $\begin{array}{l}\text { Northeast temperate } \\
\text { mixed: } 500-\text { yr burn }\end{array}$ & $\begin{array}{l}50 \% \text { continental temper- } \\
\text { ate coniferous forest, } \\
50 \% \text { temperate decidu- } \\
\text { ous forest }\end{array}$ \\
\hline 6 & $\begin{array}{l}\text { Warm temperate/subtropi- } \\
\text { cal mixed forest }\end{array}$ & $\begin{array}{l}50 \% \text { coniferous forest, } \\
50 \% \text { deciduous forest }\end{array}$ & $\begin{array}{l}\text { Southeast mixed: } 200-\mathrm{yr} \\
\text { burn/blowdown }\end{array}$ & $\begin{array}{l}33 \% \text { continental temper- } \\
\text { ate coniferous forest, } \\
33 \% \text { temperate decidu- } \\
\text { ous forest, } 34 \% \text { tem- } \\
\text { perate broadleaf ever- } \\
\text { green forest }\end{array}$ \\
\hline 7 & $\begin{array}{l}\text { Temperate deciduous for- } \\
\text { est }\end{array}$ & Deciduous forest & $\begin{array}{l}\text { Northeast deciduous: } \\
500 \text {-yr burn }\end{array}$ & $\begin{array}{l}\text { Temperate deciduous for- } \\
\text { est }\end{array}$ \\
\hline 8 & Tropical deciduous forest & Deciduous forest & $\begin{array}{l}\text { Tropical deciduous: } \\
500-\text { yr burn }\end{array}$ & Tropical forest \\
\hline 9 & Tropical evergreen forest & $\begin{array}{l}\text { Broadleaf evergreen for- } \\
\text { est }\end{array}$ & $\begin{array}{l}\text { Tropical deciduous: } \\
500-\text { yr burn }\end{array}$ & Tropical forest \\
\hline 10 & $\begin{array}{l}\text { Temperate mixed xero- } \\
\text { morphic woodland }\end{array}$ & $\begin{array}{l}50 \% \text { coniferous forest, } \\
50 \% \text { deciduous forest }\end{array}$ & $\begin{array}{l}\text { Southern mixed hard- } \\
\text { wood/ } \mathrm{C}_{3} \text { grass: } 30-\mathrm{yr} \\
\text { forest burn/4-yr grass } \\
\text { burn, annual grazing }\end{array}$ & Xeromorphic woodland \\
\hline 11 & $\begin{array}{l}\text { Temperate conifer xero- } \\
\text { morphic woodland }\end{array}$ & Coniferous forest & $\begin{array}{l}\text { Western pine } / 50 \% \mathrm{C}_{3}- \\
50 \% \mathrm{C}_{4} \text { grass mix: } \\
30-\mathrm{yr} \text { forest burn/4-yr } \\
\text { grass burn, annual } \\
\text { grazing }\end{array}$ & Xeromorphic woodland \\
\hline 12 & Tropical thorn woodland & Shrubland & $\begin{array}{l}\text { Southern mixed hard- } \\
\text { wood/C } \mathrm{C}_{4} \text { grass: } 100-\mathrm{yr} \\
\text { forest burn/3-yr grass } \\
\text { burn, annual grazing }\end{array}$ & Xeromorphic woodland \\
\hline 13 & $\begin{array}{l}\text { Temperate/subtropical de- } \\
\text { ciduous savanna }\end{array}$ & $\begin{array}{l}20 \% \text { deciduous forest, } \\
80 \% \mathrm{C}_{4} \text { grassland }\end{array}$ & $\begin{array}{l}\text { Southern mixed hard- } \\
\text { wood } / 50 \% \mathrm{C}_{3} \text { grass- } \\
50 \% \mathrm{C}_{4} \text { grass mix: } \\
30-\mathrm{yr} \text { forest burn } / 4-\mathrm{yr} \\
\text { grass burn, annual } \\
\text { grazing }\end{array}$ & $\begin{array}{l}50 \% \text { temperate deciduous } \\
\text { forest, } 50 \% \text { grassland }\end{array}$ \\
\hline 14 & $\begin{array}{l}\text { Warm temperate/subtropi- } \\
\text { cal mixed savanna }\end{array}$ & $\begin{array}{l}20 \% \text { deciduous forest, } \\
80 \% \mathrm{C}_{4} \text { grassland }\end{array}$ & $\begin{array}{l}\text { Southern mixed hard- } \\
\text { wood } / 50 \% \mathrm{C}_{3} \text { grass- } \\
50 \% \mathrm{C}_{4} \text { grass: } 30-\mathrm{yr} \\
\text { forest burn } / 4 \text {-yr grass } \\
\text { burn, annual grazing }\end{array}$ & $\begin{array}{l}17 \% \text { continental temper- } \\
\text { ate coniferous forest, } \\
16 \% \text { temperate decidu- } \\
\text { ous forest, } 50 \% \text { grass- } \\
\text { land, } 17 \% \text { temperate } \\
\text { broadleaf evergreen } \\
\text { forest }\end{array}$ \\
\hline 15 & $\begin{array}{l}\text { Temperate conifer savan- } \\
\text { na }\end{array}$ & $\begin{array}{l}20 \% \text { coniferous forest, } \\
80 \% \mathrm{C}_{3} \text { grassland }\end{array}$ & $\begin{array}{l}\text { Western pine } / 50 \% \mathrm{C}_{3}- \\
50 \% \mathrm{C}_{4} \text { grass mix: } \\
30-\mathrm{yr} \text { forest burn } / 4-\mathrm{yr} \\
\text { grass burn, annual } \\
\text { grazing }\end{array}$ & $\begin{array}{l}50 \% \text { continental conifer- } \\
\text { ous, } 50 \% \text { grassland }\end{array}$ \\
\hline 16 & $\begin{array}{l}\text { Tropical deciduous savan- } \\
\text { na }\end{array}$ & $\begin{array}{l}20 \% \text { deciduous forest, } \\
80 \% \mathrm{C}_{4} \text { grassland }\end{array}$ & $\begin{array}{l}\text { Southern mixed hard- } \\
\text { wood/ } \mathrm{C}_{4} \text { grass: } 30-\mathrm{yr} \\
\text { forest burn/4-yr grass } \\
\text { burn, annual grazing }\end{array}$ & $\begin{array}{l}50 \% \text { tropical forest, } 50 \% \\
\text { grassland }\end{array}$ \\
\hline 17 & $\mathrm{C}_{3}$ grasslands & $\mathrm{C}_{3}$ grasslands & $\mathrm{C}_{3}$ grass: annual grazing & Grassland \\
\hline 18 & $\mathrm{C}_{4}$ grasslands & $\mathrm{C}_{4}$ grasslands & $\begin{array}{l}\mathrm{C}_{4} \text { grass: } 3 \text {-yr grass burn, } \\
\text { annual grazing }\end{array}$ & Grassland \\
\hline 19 & Mediterranean shrubland & Shrubland & $\begin{array}{l}\text { Chaparral: } 30-y r \text { shrub } \\
\text { burn }\end{array}$ & Xeromorphic woodland \\
\hline 20 & Temperate arid shrubland & Shrubland & $\begin{array}{l}\text { Sage } / 75 \% \mathrm{C}_{3}-25 \% \mathrm{C}_{4} \\
\text { grass: } 30 \text {-yr shrub } \\
\text { burn/4-yr grass burn }\end{array}$ & Shrubland \\
\hline 21 & $\begin{array}{l}\text { Subtropical arid shrub- } \\
\text { land }\end{array}$ & Shrubland & $\begin{array}{l}\text { Creosote } 50 \% \mathrm{C}_{3}-50 \% \mathrm{C}_{4} \\
\text { grass: } 30-\mathrm{yr} \text { shrub } \\
\text { burn } / 4-\mathrm{yr} \text { grass burn }\end{array}$ & Shrubland \\
\hline
\end{tabular}


TABLE 2. Comparison of biogeochemical and physiological processes, and compartments among the biogeochemistry models employed in VEMAP.

\begin{tabular}{|c|c|c|c|}
\hline Process & Biome-BGC & Century & TEM \\
\hline Temporal scale & Daily/annual & Monthly & Monthly \\
\hline Equilibrium & $\begin{array}{l}\text { Carbon pools specified so } \\
\text { NEP }=0 \text { after } 1 \mathrm{yr}\end{array}$ & $\begin{array}{l}\text { Simulation with repeated } \\
\text { disturbance for } 2000 \mathrm{yr}\end{array}$ & $\begin{array}{l}\text { Dynamic simulation (10- } \\
3000 \text { yr) until } \mathrm{C} \text { and } \mathrm{N} \\
\text { pools balance (e.g., } \mathrm{N} \text { in- } \\
\text { put }=\mathrm{N} \text { loss })\end{array}$ \\
\hline $\begin{array}{l}\text { Potential evapotranspiration } \\
\text { (PET)/evapotranspiration } \\
\text { (ET) }\end{array}$ & Penman-Monteith & Modified Penman-Monteith & Jensen-Haise (1963) \\
\hline Number of soil water layers & 1 & 5 & 1 \\
\hline $\begin{array}{l}\text { Number of vegetation carbon } \\
\text { pools }\end{array}$ & 4 & 8 & 1 \\
\hline $\begin{array}{l}\text { Number of litter/soil carbon } \\
\text { pools }\end{array}$ & 3 & 13 & 1 \\
\hline $\begin{array}{l}\text { Number of vegetation nitrogen } \\
\text { pools }\end{array}$ & 4 & 8 & 2 \\
\hline $\begin{array}{l}\text { Number of litter/soil nitrogen } \\
\text { pools }\end{array}$ & 3 & 15 & 2 \\
\hline Leaf Area Index (LAI) & $\begin{array}{l}\text { Water balance } \dagger, \mathrm{N} \text { availabil- } \\
\text { ity and gross photosynthe- } \\
\text { sis }\end{array}$ & Leaf biomass & Not explicitly calculated \\
\hline Plant respiration $Q_{10}$ & 2.0 & 2.0 & $1.5-2.5$ \\
\hline Decomposition $Q_{10}$ & 2.4 & $\sim 2.0$ & 2.0 \\
\hline Stomatal conductance $=f\left(C_{a}\right)$ & Yes & Implicitly & No \\
\hline$C_{i}=f\left(C_{a}\right)$ & Yes & Not applicable & Yes \\
\hline Vegetation $\mathrm{C} / \mathrm{N}=f\left(C_{a}\right)$ & Yes & Yes & No \\
\hline Carbon uptake by vegetation & Farquhar & Multiple limitation NPP & Multiple limitation GPP \\
\hline Nitrogen uptake by vegetation & Annual & Monthly & Monthly \\
\hline $\begin{array}{l}\text { Net nitrogen mineralization } \\
\left(\mathrm{N}_{\min }\right)\end{array}$ & $\mathrm{C} / \mathrm{N}$ ratio controlled & $\begin{array}{l}\text { Multiple compartment miner- } \\
\text { alization/immobilization }\end{array}$ & $\begin{array}{l}\text { Mineralization/immobiliza- } \\
\text { tion dynamics }\end{array}$ \\
\hline
\end{tabular}

$\dagger$ For the VEMAP activity, LAI is a function of water balance only; $C_{a}$ is atmospheric concentration; $C_{i}$ is internal $\mathrm{CO}_{2}$ concentration within a "leaf"'; NPP is net primary production; GPP is gross primary production.

conditions, using allometric relationships, but then, because of computing constraints run for just one year. (Biome-BGC, uses a daily time step and required more computer time to run to steady state for the entire VEMAP grid than was available to Running and collaborators; S. W. Running, personal communication.) Century was run to steady state for grasslands. For forests, Century does not achieve a steady-state condition. Instead, forest results were reported at the ages corresponding to the age of TEM's calibration stands, ages that varied by vegetation type (Table 2). Century forest results may have nonzero NEP, thereby differing from the other two models. Thus, all three models require an implicit or explicit assumed stand age linking this study to knowledge of, and assumptions about, forest demography at large scales (see Table 1).

\section{Experimental protocol}

The entire VEMAP experimental protocol was factorial, including effects of climate change, increasing atmospheric $\mathrm{CO}_{2}$, and redistribution of vegetation types (VEMAP 1995, Kittel et al. 1995). In this paper, we consider only simulations using current climate, current atmospheric $\mathrm{CO}_{2}(354 \mu \mathrm{L} / \mathrm{L})$, and potential natural vegetation derived from Küchler (1964). The models were run using a common spatial format $\left(0.5 \times 0.5^{\circ}\right.$ grid) containing 3261 land grid cells. Climate, soil, and vegetation data, along with climate change scenarios, are available; see Acknowledgments.
Required soil properties (depth, water holding capacity, and texture: percentage sand, silt, clay) were based on Kern's (1994, 1995) 10-km gridded United States Natural Resource Conservation Service data base (NATSCO). Soil carbon was also gridded from Kern's (1994) data base as a validation variable. We used cluster analysis to group the $10-\mathrm{km}$ soil units into one to four "modes" within each grid cell. Soils within clusters have quantitatively similar (in a multivariate sense) soil properties. We averaged soil properties within the areally dominant mode, thus averaging the properties of generally similar soils, and assigned those properties to the cell. This avoided two problems, the first being the threat of averaging diverse soils to yield a type that might not actually occur in the grid cell (e.g., sand averaged with clay to yield a loam). In our approach soils within clusters can differ by a few percent in texture or organic matter but never by $10-20 \%$; i.e., not by the differences between major texture classes. The second problem we avoided was in diverse regions where the single most common soil type might compose a plurality (rather than the majority) of the cell. Using our algorithm, we average soil properties within the areally dominant mode, thereby averaging quantitatively similar soils together. Thus the single, areally dominant soil could be a sandy type, but the majority of the grid cell could be an array of clayey soils ranging in texture from 28 to $35 \%$ clay. In our algorithm these clay soils would be aggregated together 
to assign the average texture for the cell instead of using the areally dominant sandy soil.

\section{Satellite data}

Data from the NASA/NOAA Pathfinder Program were used to produce satellite vegetation indices for use in model evaluation. The Pathfinder land data set (see Acknowledgments) is derived from measurements made by the Advanced Very High Resolution Radiometer (AVHRR) on board the NOAA TIROS-N series of polar orbiting satellites. The optical data are calibrated for reflectance. The data are projected onto an $8 \times 8 \mathrm{~km}$ equal-area grid and temporally composited to scenes within 10-d windows from the original daily data. The Pathfinder processing also includes cloud screening and partial atmospheric correction (for ozone and Raleigh scattering). The normalized difference vegetation index (NDVI) can be computed from the two AVHRR optical channels (Tucker 1979, Goward et al. 1991).

There have been many studies that relate the NDVI to ecological quantities at local, regional, and global scales (Asrar et al. 1984, Fung et al. 1987). Most relevant for this study, the growing season integral of the NDVI is related to terrestrial net primary productivity (Goward et al. 1985) based on good empirical correlations and a strong theoretical basis (Goward et al. 1985, Sellers 1985, Fung et al. 1987, Schimel et al. 1991, Potter et al. 1993). Although there is uncertainty involved in calculating NPP from the NDVI because of atmospheric and geometric bidirectional effects and vegetation type-specific relationships, it is robust as a proxy. Also, by recompositing and averaging, we minimized these effects. NDVI has the important advantage of being an actual measurement made everywhere in the study domain, rather than being interpolated or extrapolated to a map, as is mapped soil organic carbon (SOC) (Schimel and Potter 1995).

We produced a data set that is the annual integral of NDVI (iNDVI) averaged over the $3 \mathrm{yr}$ of Pathfinder data available at the time of this study (1986-1988). We first extracted the continental United States from the global grid and recomposited the data to monthly scenes by choosing the greenest pixels (an additional and conservative technique for minimizing cloud and sun/sensor angular geometry effects). The monthly values were then averaged for each pixel, and the twelve resulting maps reprojected to the VEMAP $0.5 \times 0.5^{\circ}$ grid. The iNDVI values were then divided by 12 to retain the familiar $[-1,1]$ range for NDVI.

\section{Data analysis}

In order to separate continental and within-vegetation type variations and to identify patterns of agreement and disagreement between models on a grid cellto-grid cell level, we carried out a simple data transformation. We computed the "mean deviates" of gridded values for each variable and model to create a transformed variable by subtracting the mean from each value. For our analyses, the transformation was such that for each variable $X$ in each grid cell $(i, j)$ in each vegetation class $V$, the mean deviate of $X_{\mathrm{V}}(i, j)$ was:

$$
\operatorname{MD}_{\mathrm{v}}(i, j)=X_{\mathrm{v}}(i, j)-\bar{X}_{\mathrm{v}}
$$

where $\bar{X}_{\mathrm{v}}$ is the mean for variable $X$ within vegetation class V. Transformed variables $X_{\mathrm{V}}$ included outputs such as NPP, total carbon storage, and evapotranspiration, and inputs such as annual precipitation or soil clay content. We also computed the mean deviates of the iNDVI and mapped SOC as model evaluation variables. By subtracting the mean, we eliminated modelto-model bias in the mean, and the large between-vegetation type differences in model results. We subtract the vegetation type-specific means (rather than the continental average) because the models use different parameterizations for the different vegetation types, and so the biases and type-to-type effects are type specific. The mean deviates allow us to examine patterns in spatial variability within vegetation types, but in the continental aggregate.

\section{RESULTS \\ Analysis of mean deviates}

Mean deviates of the original data were used to visualize the degree of spatial variability within vegetation types for each model. We then collapsed the mean deviates into continental-scale distributions, as displayed in Figs. 3, 4, and 5. Analysis of the mean deviates shows different patterns of variability for both different models and different variables. In all three models, the mean deviates of vegetation carbon are small (Fig. 3a-c), likely because of the assumption of a uniform stand age (explicitly, as in Century, implicitly in TEM and BGC). Soil carbon shows quite a different pattern, with a wide range of mean deviates for $\mathrm{BGC}$, a narrow range for TEM, and Century intermediate (Fig. 3d-f). The mean deviates for nitrogen mineralization and evapotranspiration are similar across models (Fig. 4a-f). Total carbon and NPP show patterns similar to soil carbon, with broad, intermediate, and narrow ranges of mean deviates for BGC, Century, and TEM, respectively (Fig. 5a-f).

BGC consistently simulated large variations in ecosystem processes within vegetation types and TEM simulated small variations. Century is intermediate in its simulation of spatial variability. We cannot assess rigorously which, if any, simulated patterns of spatial variability are correct, but this analysis provides a foundation for additional data analysis or collection needed in model validation. TEM's generally low spatial variability is consistent with a view that at the VEMAP grid scale, typical high stand-to-stand variability averages out. By contrast, Biome-BGC preserved the level of variability typical of hectare-to-hectare variability in field studies at the VEMAP grid scale. These patterns 

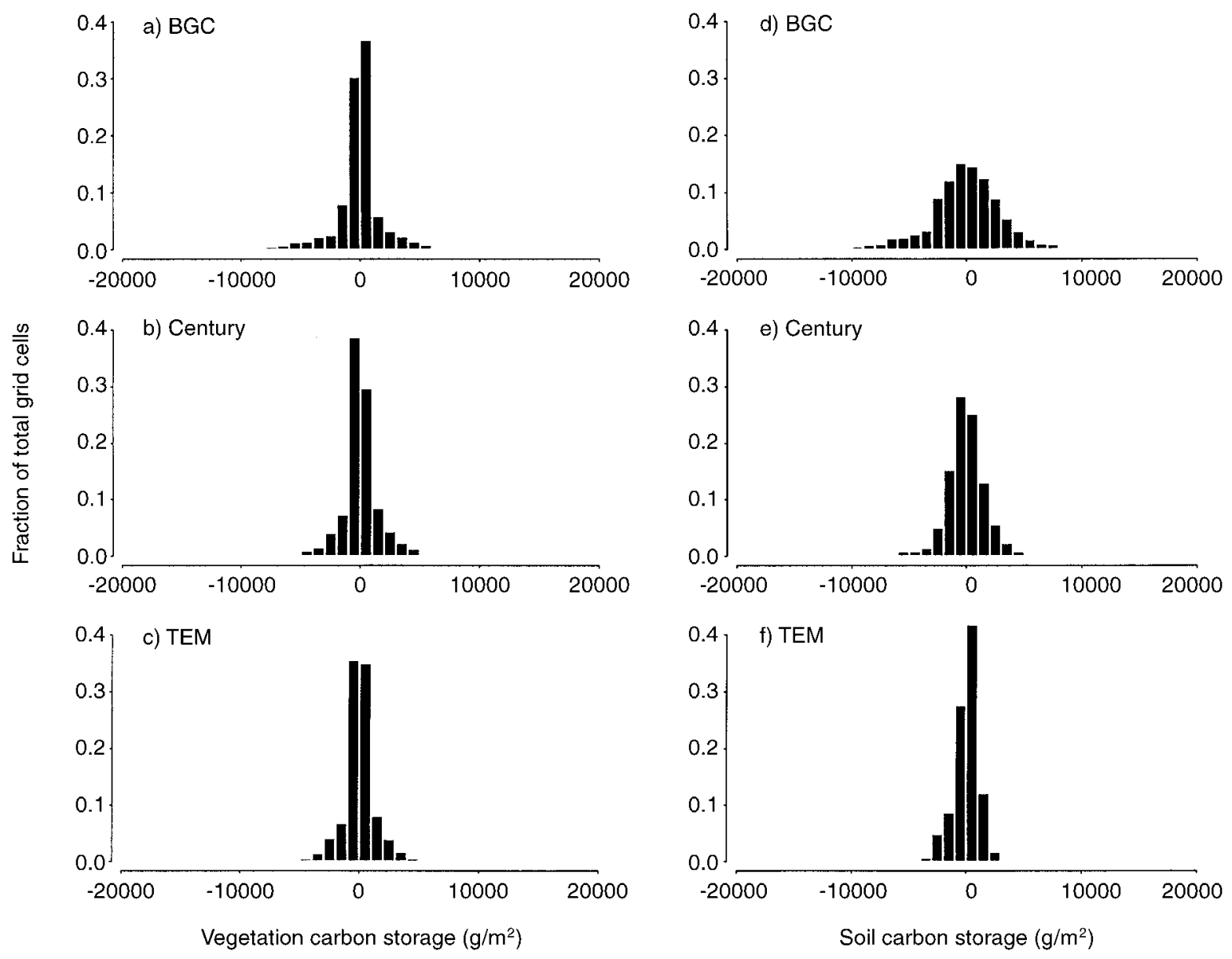

FIG. 3. This figure and Figs. 4 and 5 show the mean deviates from each vegetation class mean (Eq. 1) collapsed into a single continental distribution. Mean deviates of vegetation carbon storage for (a) BGC, (b) Century, and (c) TEM, and mean deviates of soil carbon storage for (d) BGC, (e) Century, and (f) TEM are shown.

of variability are based on continental distributions: note that the three models are quite similar in some ecosystem types (Fig. 6). Although few data exist or are formatted to allow testing these different predictions, model differences in spatial variability can be tested by appropriate field sampling.

\section{Spatial distribution of mean deviates}

Model-simulated patterns of spatial variability can also be visualized by mapping the mean deviates. Fig. 7 shows the mapped mean deviates for each model for NPP (Fig. 7a-c) and ET (Fig. 7d-f). The values mapped are the mean deviates, so the color indicates how different a given grid cell is from the average for the vegetation class it lies within. For ET (Fig. 7d-f) the overall spatial patterns are similar for the three models, supporting earlier conclusions that model-simulated ETs are well-correlated. All three models show a dramatic gradient across the Great Plains, reflecting the gradient from arid (low precipitation and high ET) to mesic (high precipitation and moderate to high ET) sites.
For NPP, Century and BGC simulate similar patterns of spatial variability, although BGC's overall range is larger. For example, the gradient in NPP across the Great Plains, evident in ET, is also evident in NPP. Century and BGC generally simulate larger gradients in NPP within vegetation types than TEM. TEM's spatial variability is generally subdued relative to the other models (see also Fig. 6).

\section{Mechanistic inference from mean deviates}

The analysis of the mean deviates suggests differences exist in the patterns and magnitude of spatial variability. In VEMAP (1995), it was argued that BGC's behavior was dominated by bioclimatic effects, whereas TEM's was dominated by nutrient cycling controls. By plotting water- or nutrient-related mean deviates against each other to reveal the spatial correlation, the strengths of these relationships can be visualized. Fig. 8 shows the spatial variability of mean deviates for NPP, ET, and nitrogen mineralization plotted against each other. All three models show highly significant relationships $(P<0.05)$ between NPP and 

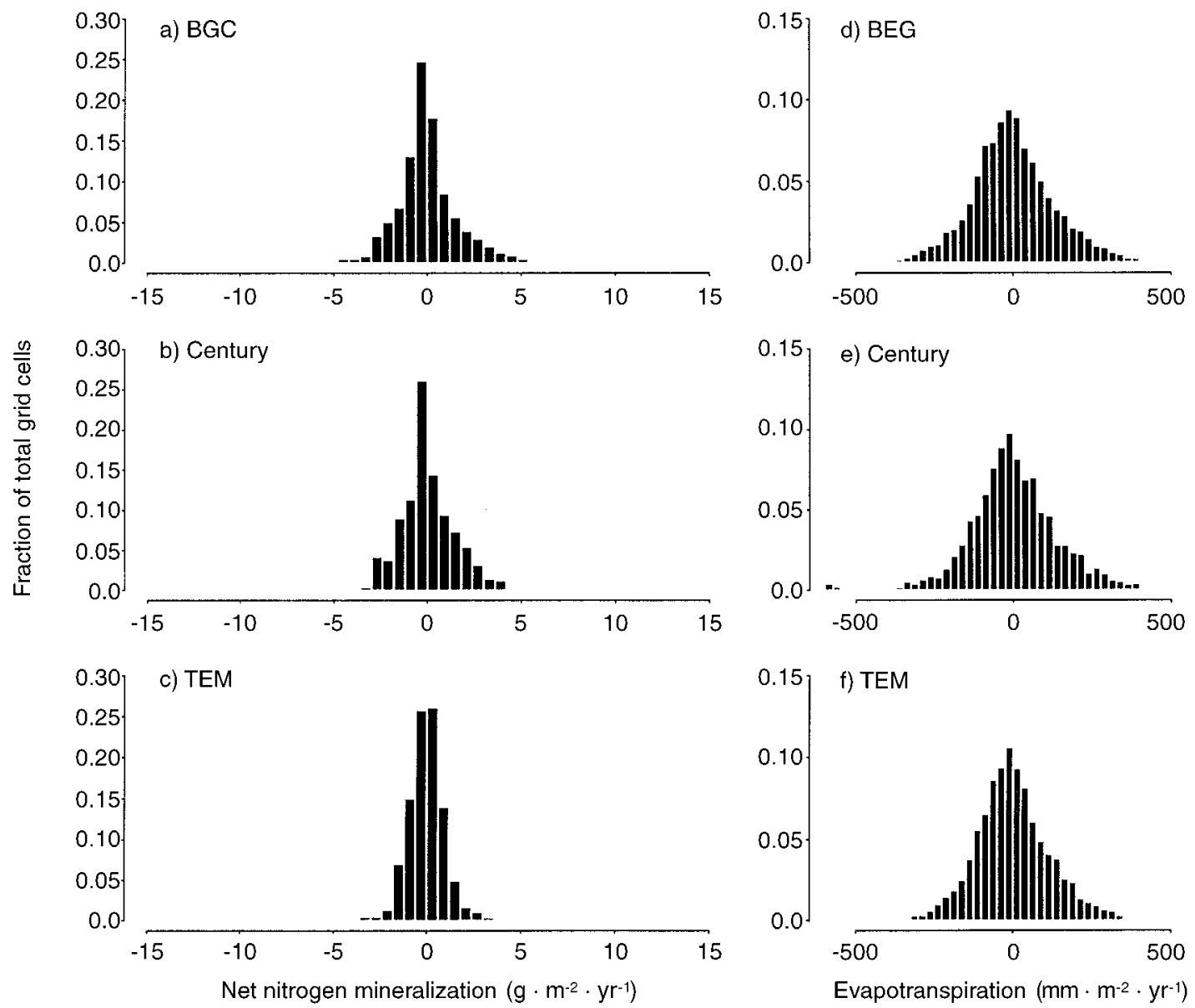

FIG. 4. Mean deviates of net nitrogen mineralization for (a) BGC, (b) Century, and (c) TEM, and mean deviates of annual evapotranspiration for (d) BGC, (e) Century, and (f) TEM are shown.

nitrogen mineralization, but the relationships are clearly stronger in Century and TEM than in BGC. In all three models, spatial variations in NPP are coordinated with changes in nitrogen. Similarly, in all three models, changes in NPP vary together and significantly with changes in ET. The relationship is stronger in Century and BGC than in TEM, partly because the ranges of NPP mean deviates simulated in Century and BGC are larger than in TEM. Finally, in Century and BGC, nitrogen mineralization and ET are correlated $\left(R^{2} \mathrm{~S}\right.$ of $0.7-$ $0.75)$, whereas in TEM there is a substantially lower correlation $\left(R^{2}=0.34\right)$ between the mean deviates of ET and nitrogen mineralization (Fig. 8). This may be because in TEM the water budget is calculated independently of, rather than interactively with, the biogeochemistry (McGuire et al. 1993).

In all three models, water and nutrient controls of NPP become correlated at steady state. In Century, this occurs because precipitation influences nutrient inputs (positively), losses to leaching and trace gases (positively), nutrient mineralization (positively until anaerobiosis is reached), and plant production (positively). Thus, as precipitation increases, nitrogen flux increas- es, because higher precipitation leads to both higher inputs and higher outputs. Increasing precipitation directly increases the potential for plant production, whereas the accompanying increase in $\mathrm{N}$ flux also allows for higher plant $\mathrm{N}$ uptake. Plant uptake captures nitrogen into a range of living and (subsequently) detrital and soil organic matter pools whose turnover then contributes to $\mathrm{N}$ availability. Turnover of detritus and soil organic matter is a key control over $\mathrm{N}$ availability for plant uptake at steady state. These cyclic interactions among nitrogen flux, plant production, and nitrogen capture in organic matter lead to correlation of water and nutrient limitation at steady state, as can be visualized in Fig. 8. Deviations from linear relationships arise because of within- and between-vegetation type differences in carbon:nitrogen ratios and water use efficiency, which affect the stoichiometry among water, nitrogen, and organic matter produced. Similar interactions lead to the water-nitrogen-NPP correlations in Biome-BGC and TEM, although in these models the $\mathrm{N}$ inputs and outputs are not simulated explicitly as functions of precipitation.

There are numerous studies that, taken together, 

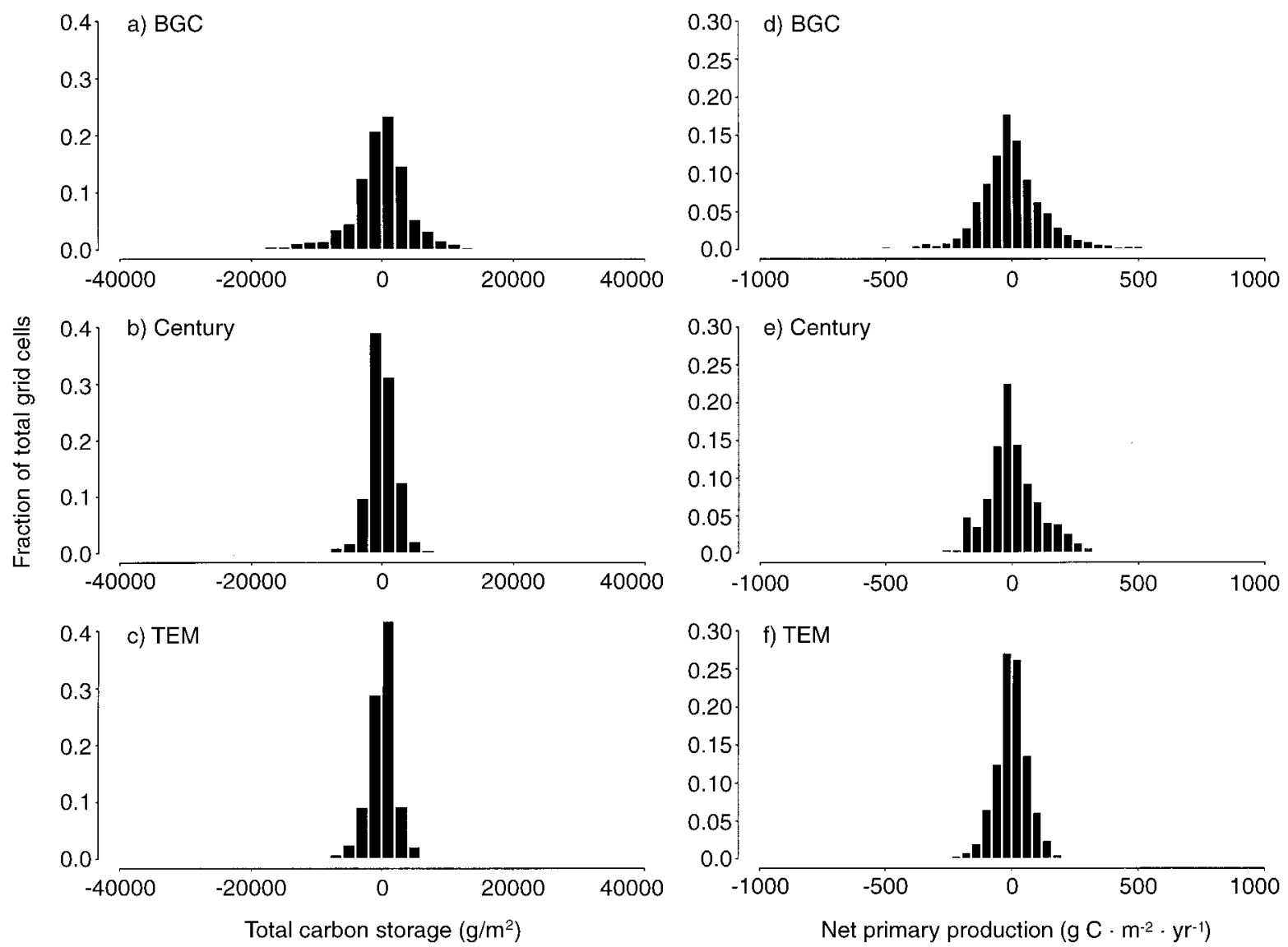

FIG. 5. Mean deviates of total carbon storage for (a) BGC, (b) Century, and (c) TEM, and mean deviates of net primary production for (d) BGC, (e) Century, and (f) TEM are shown.

show that spatial patterns of NPP may be explained using either water and climatic variables (e.g., Sala et al. 1988) or by using models that include biogeochemistry (e.g., Parton et al. 1987). In addition, some studies suggest that systems can switch between primary limitation by nutrients and other variables (Holland et al. 1992). The simulations presented herein provide a hypothesis to explain such seemingly paradoxical results (see also Schimel et al. 1991).

When NPP is plotted against vegetation carbon, strong relationships are evident in all three models, but with intriguing differences (Fig. 9). BGC shows a clear but noisy NPP-vegetation carbon correlation. Century's relationship is tighter, but substantial scatter is evident, and forests, grasslands, and savannas have different slopes. In TEM, each vegetation type has an unique slope, with no scatter. TEM simulates NPP as if NPP were determined by a fixed fractional turnover of biomass. This occurs because at equilibrium, TEM requires that NPP $=$ litterfall, and litterfall is determined as a constant fraction of biomass for each vegetation type, resulting in the simulated NPP-vegetation carbon relationships (McGuire et al. 1993, VEMAP 1995). By definition NPP and litterfall must be equal at steady state. In Biome-BGC and Century, allocation and hence biomass turnover (litterfall/biomass) varies allometrically between grid cells depending upon the amount of vegetation carbon, causing scatter within vegetation types. In Century and Biome-BGC, the biomass turnover relationship is determined for each grid cell rather than being constant for vegetation types as is the case for TEM. Additionally, Century was not constrained to a strict steady state $(\mathrm{NEP}=0)$, and so NPP was not required to equal litterfall, adding to variability.

There were also large differences between the spatial patterns of soil carbon among the three models. The cause of some of this disagreement is evident in Fig. 10. BGC shows a clear relationship between soil carbon and NPP that does not occur in the other models (results not shown). This produces a spatial pattern in soil carbon in BGC related to patterns in NPP that does not exist in the other two models, resulting in large differences between model pairs including BGC.

\section{DISCUSSION}

\section{Model Evaluation}

The analysis of spatial variability in the three models provides information about the effects of different 

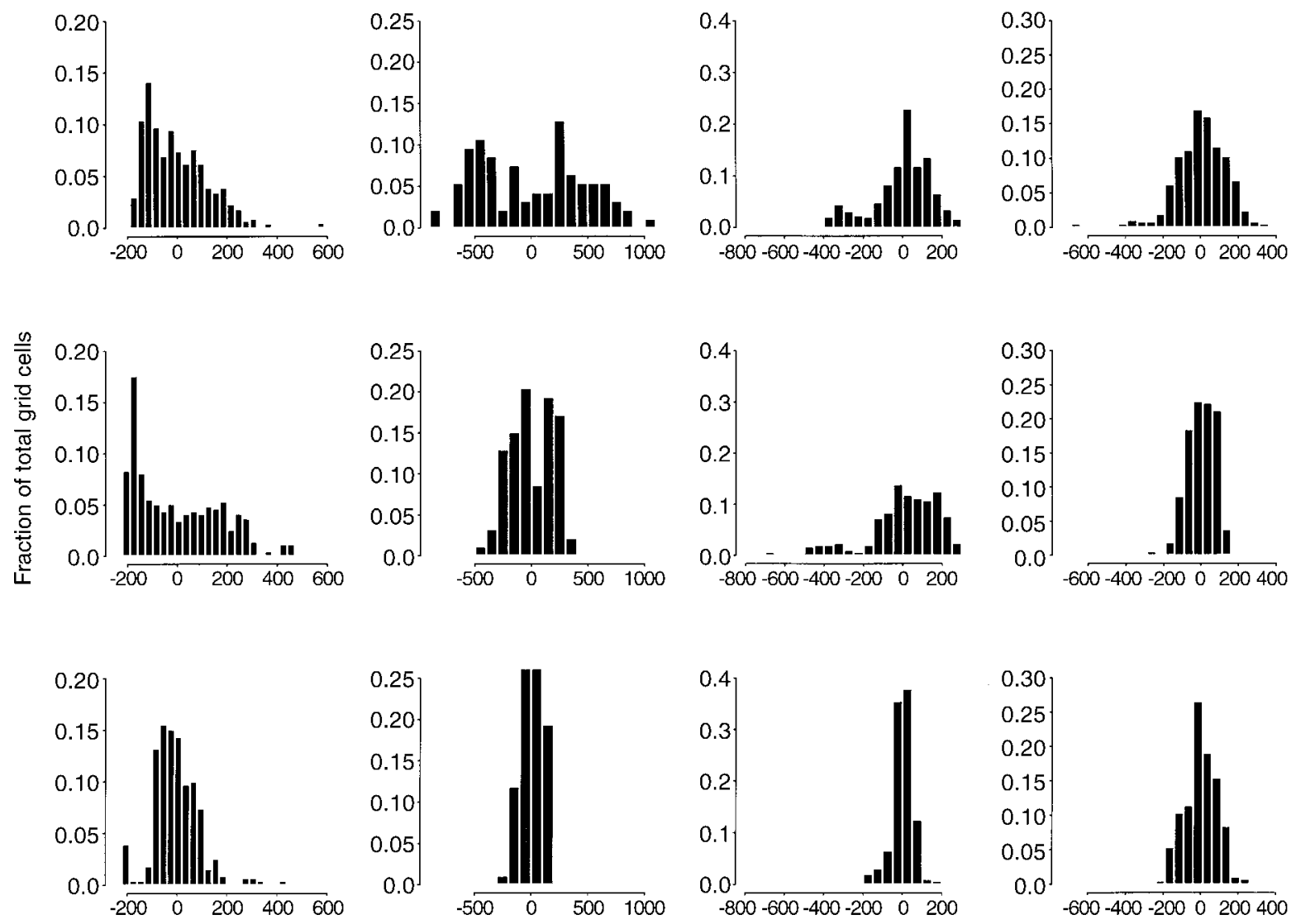

Within-ecosystem variations of NPP $\left(\mathrm{g} \mathrm{C} \cdot \mathrm{m}^{-2} \cdot \mathrm{yr}^{-1}\right)$

FIG. 6. Mean deviates of NPP for four specific vegetation types. Across, from left to right: $\mathrm{C}_{4}$ grasslands, maritime coniferous forest, mixed savanna, temperate deciduous forests. Vertically, from top to bottom, BGC, Century, and TEM.

modeling approaches on simulated variability, but does not resolve whether the simulated patterns are capturing actual patterns of variability. Experiments such as VEMAP raise challenges for traditional notions of model "validation." Successful validation at specific sites does not guarantee successful simulation of spatial variability. All three models (TEM, Century, and BGC) have been extensively validated at specific sites (e.g., McGuire et al. 1993, Parton et al. 1994, Running 1994), yet differ substantially in their simulation of spatial variability within vegetation types. We present a comparison of modeled and observed NPP along environmental gradients within the maritime coniferous vegetation type and the $\mathrm{C}_{4}$ grasslands (Schimel et al. 1985, 1991, Runyon et al. 1994). This comparison is presented to illustrate both the problems of using traditional site-specific data, and the opportunities presented by site data collected along environmental gradients for spatial validation (as opposed to, for example, the strategy of intensive time-series sites in "typical" situations). We also compared model results to spatially explicit gridded data sets, the annual integral of the NDVI (Tucker et al. 1986), and SOC; the last based on USDA-NRCS analyses (Kern 1994) aggregated to the VEMAP grid.

Few field studies have addressed gradients of processes or state variables within vegetation types; this type of information is crucial for testing spatial ecosystem models. It is unusual to have comprehensive measurements of modeled quantities available for evaluating large-scale simulations. Further, when such measurements exist, they are intrinsically made at scales smaller than the grid resolution of the simulation and extrapolated, as in the mapping of soil properties. For example, in VEMAP, the grid resolution is $0.5^{\circ}$, and climate, soil, and vegetation properties assigned are deemed to be representative of that large area (hundreds of square kilometers). Yet grassland NPP is measured on plots $<1 \mathrm{~m}^{2}$ and varies on length scales of tens to hundreds of meters, and forests are similarly measured on hectare scales (Schimel et al. 1991, Runyon et al. 1994). Comparisons of mapped and modeled results are more difficult because measurements may be made at sites with conditions different from the $0.5 \times 0.5^{\circ}$ average specified for the grid cell. It is difficult to distinguish between model failure and the effects of such 


\section{a) BGC}

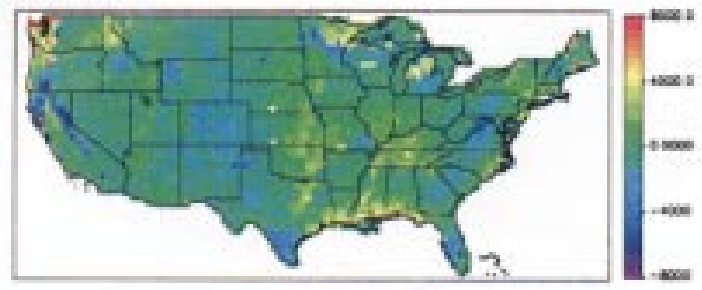

\section{b) Century}

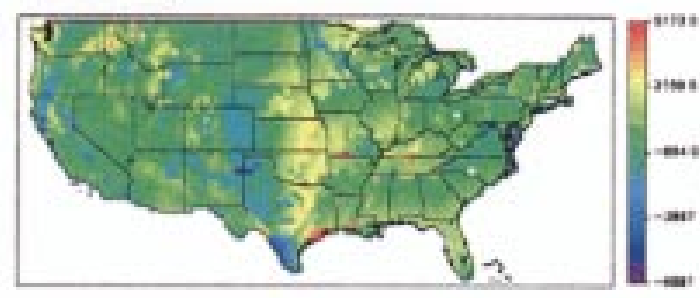

c) TEM

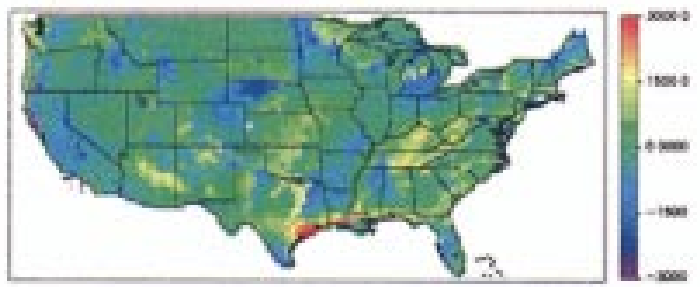

d) $B G C$

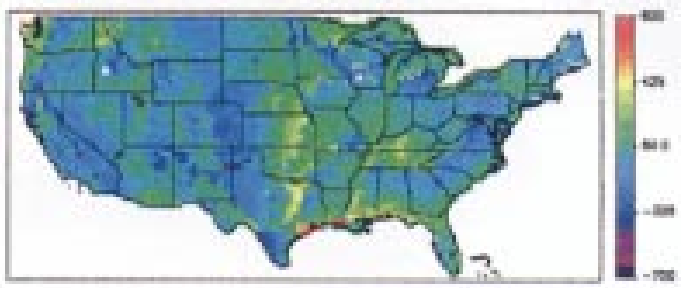

e) Century

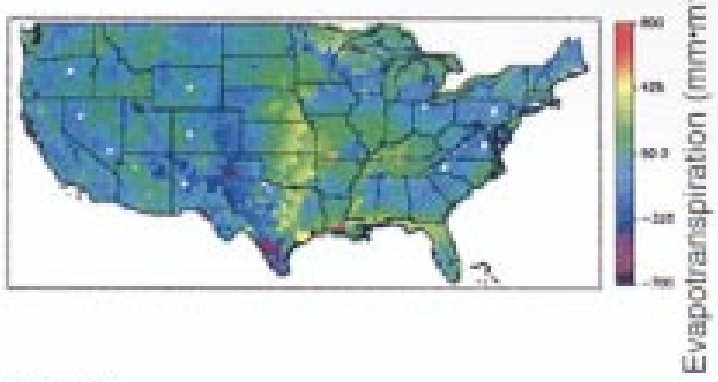

f) TEM

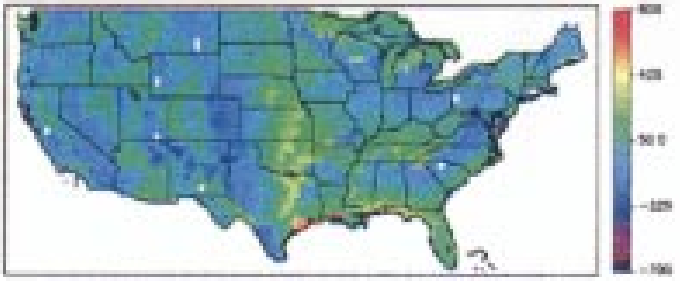

FIG. 7. Mapped mean deviates, showing the spatial distributions of grid cells with large positive and negative deviations from vegetation type means. Maps a-c show mapped mean deviates for NPP for BGC, Century, and TEM, respectively, and maps $\mathrm{d}-\mathrm{f}$ similarly show mapped mean deviates for annual evapotranspiration.

scale-dependent environmental differences. These environmental differences could occur either because of the topographic or edaphic setting of the measurement station, or because the field observations were made in a year with weather different from the conditions specified in the climatology. Measurements along environmental gradients minimize the above problems.

In a recent field study, the Oregon Transect Study (OTTER) (Running 1994), the NPP gradient was measured along the precipitation gradient in the Cascades of Oregon. Although VEMAP maps this region as being within the maritime coniferous vegetation type, several of the sites have actual vegetation that differs from that type, reducing the clarity of the comparison. Note also the comparison between the observed and gridded climate ranges within the vegetation type (Fig. 2a and b), which are similar but not identical. The measured NPP gradient was estimated to be $\approx 1000 \mathrm{~g} \mathrm{C} \cdot \mathrm{m}^{-2} \cdot \mathrm{yr}^{-1}$ from arid to humid (Law and Waring 1994, Runyon et al. $1994)$, a range within that modeled by BGC $(\approx 2000 \mathrm{~g}$ $\left.\mathrm{C} \cdot \mathrm{m}^{-2} \cdot \mathrm{yr}^{-1}\right)$, close to that of Century $(\approx 900 \mathrm{~g}$ $\left.\mathrm{C} \cdot \mathrm{m}^{-2} \cdot \mathrm{yr}^{-1}\right)$, and substantially larger than that of TEM $\left(\approx 500 \mathrm{~g} \mathrm{C} \cdot \mathrm{m}^{-2} \cdot \mathrm{yr}^{-1}\right)$ (see Fig. 6). A site-specific comparison shows more complex relationships. First, note that the site mean annual precipitation values (MAPs) are quite different from the MAPs of the corresponding grid cells. In many cases, OTTER observed MAP values differ by $>50 \%$ from corresponding VEMAP grid cell values. Fig. 11 shows the relationships between modeled and observed NPP and mean annual precipitation. Table 3 shows the site mean and VEMAP grid cell MAP values, and estimated and modeled NPP values. For OTTER site numbers 5 and 6 , which lie within one VEMAP grid cell, the site MAP values are 540 and $220 \mathrm{~mm} / \mathrm{yr}$, whereas the grid cell value is 330 $\mathrm{mm} / \mathrm{yr}$. Clearly, model-data comparisons must take into account these sorts of discrepancies.

To account for climate discrepancies, we compared NPP normalized against MAP (Fig. 11). Each model reproduced the observed relationship between NPP and MAP across parts, but different parts, of the precipitation gradient. BGC best matched the data at MAP $<1500 \mathrm{~mm} / \mathrm{yr}$, but produced a substantial overestimate at the two wettest sites. Century and TEM agree well 

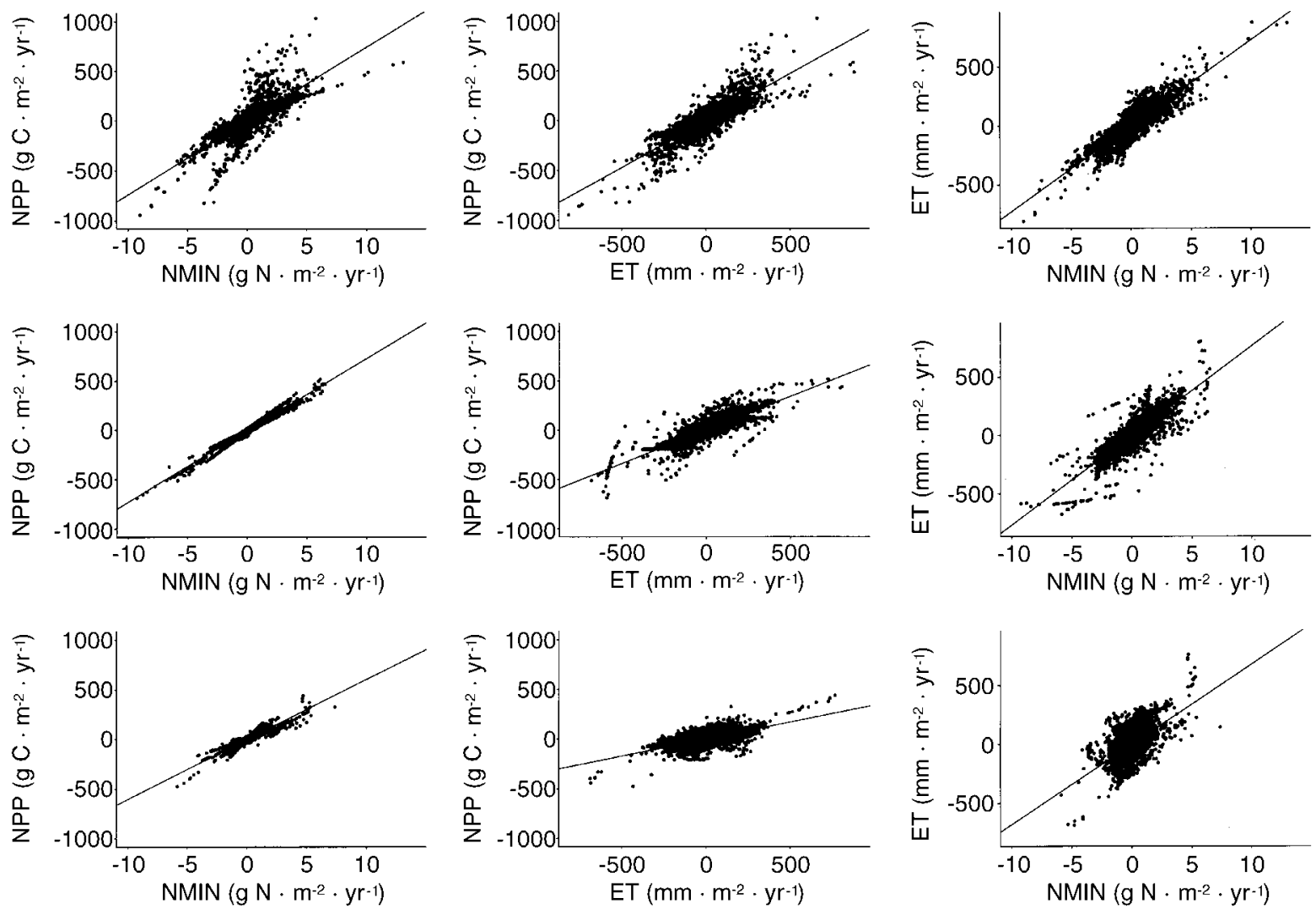

FIG. 8. Relationships between spatial changes in variables, illustrated by plotting mean deviates for two variables against one another. Across: NPP vs. nitrogen mineralization, NPP against annual evapotranspiration, and nitrogen mineralization against annual evapotranspiration. Vertically, top to bottom: BGC, Century, and TEM.

with observations at the dry and wettest extremes but underestimate the intermediate sites. The three models differ dramatically at MAP > $2000 \mathrm{~mm} / \mathrm{yr}$ : observations suggest the lower simulated values may be more realistic. In all three models, MAP and NPP are significantly correlated $\left(0.7<R^{2}<0.95, P \mathrm{~S}<0.05\right)$; this relationship is much weaker and nonsignificant in the observations, reflecting the higher diversity of other climate variables (e.g., temperature or radiation), growth forms, stand age, and other factors. BiomeBGC's NPP is the most highly correlated with MAP $\left(R^{2}=0.95\right)$; the correlations in TEM and Century are not as strong $\left(R^{2} \mathrm{~S}\right.$ of $\left.0.78-0.79\right)$, indicating the tighter linkage of NPP to hydrology in Biome-BGC relative to the other models.

We also verified model results against data from the Konza and CPER Long Term Ecological Research (LTER) sites, as data from these sites were used in model development by all three groups (Table 3, Schimel et al. 1985, 1991). For both sites, the range of observed NPP values represents variability along hillslopes resulting from soil changes and run-on, run-off relationships (Schimel et al. 1985, 1991). The best belowground production data are from a single site (Milchunas and Lauenroth 1992). In this comparison, the site and grid MAPs are close (310 vs. $380 \mathrm{~mm} / \mathrm{yr}, 835$ vs. $901 \mathrm{~mm} / \mathrm{yr}$ ). Century and BGC simulate values near the low end of the estimated NPP range for CPER, whereas TEM simulates a value near the upper end. Differences at the CPER occur because the Century and Biome-BGC groups calibrated their models to represent an assumed areally dominant landscape position (unproductive uplands, NPP of $\approx 120 \mathrm{~g} / \mathrm{m}^{2}$ ) whereas the TEM group assembled a carbon budget for calibration using the most complete data sets, collected in productive sites $\left(\mathrm{NPP} \approx 200 \mathrm{~g} / \mathrm{m}^{2}\right)$. Productive sites may have deeper-than-average soils and/or receive additional water through runoff or throughflow. The effects of landscape variability on model development and validation highlights the need for close coordination of modeling and field studies to ensure that data are used appropriately. The three models agree closely at Konza but all simulate values characteristic of productive lowland sites with deep soils (corresponding to the VEMAP grid soil properties) rather than landscape-average values (Schimel et al. 1991).

In both the $\mathrm{C}_{4}$ grassland and maritime coniferous forest comparisons, the three models usually simulate values within observational constraints, but with significant differences. The effects of soil properties and effective precipitation (as modified by water-holding capacity, runoff and run-on) (Running 1994) within 


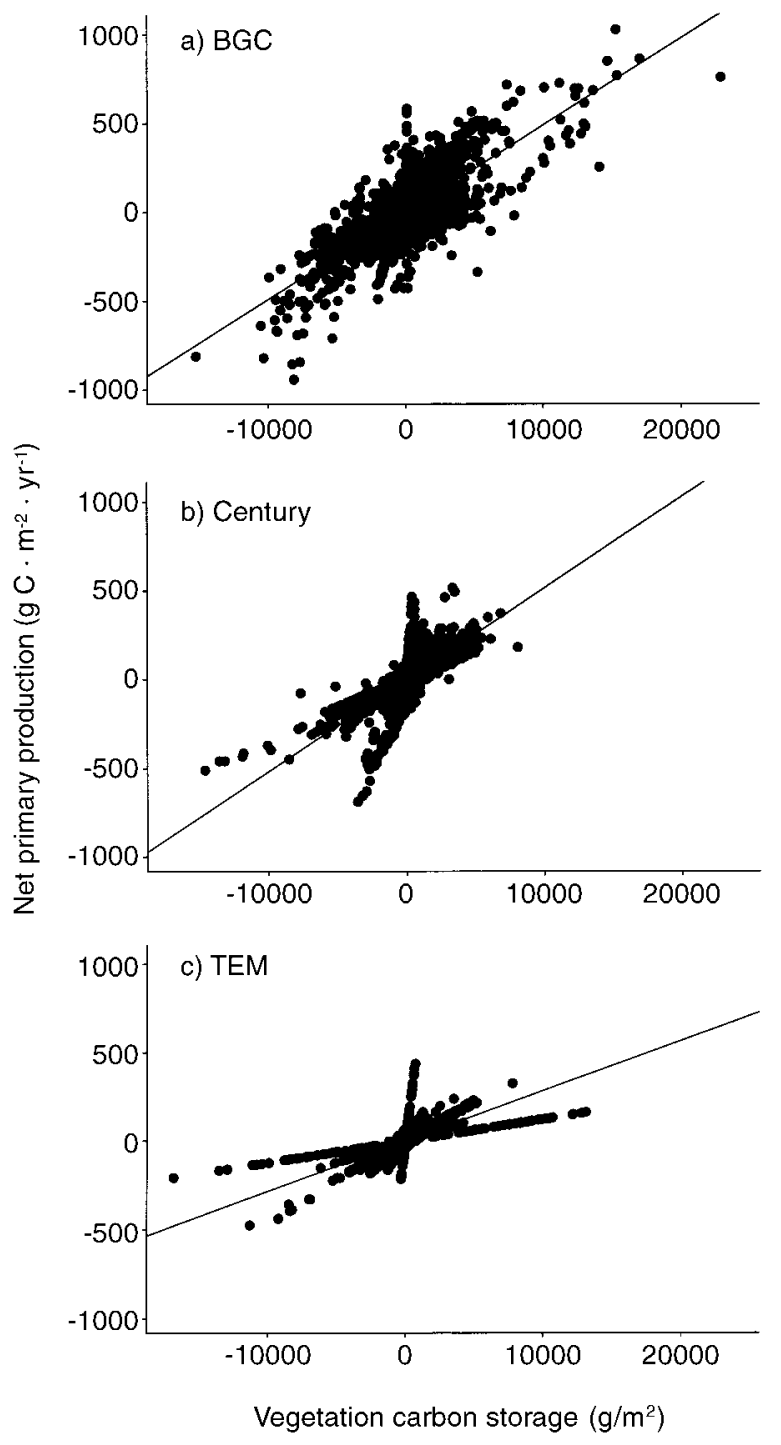

FIG. 9. Mean deviates of NPP vs. vegetation carbon storage.

landscapes greatly complicates comparison of smallscale site observations with models representing broad area averages. The agreement in site-specific comparisons is perhaps greater than would be expected from the differences in distributions illustrated in Fig. 6, and suggests that the largest intermodel differences occur in grid cells whose environmental conditions differ greatly from modal conditions for a given vegetation type. Environmental conditions at the sites considered above, although spanning considerable ranges, are not extreme for the vegetation types being examined (Fig. $2 \mathrm{a}$ and $\mathrm{b}$ ).

VEMAP simulations were done using a "potential natural" vegetation map whereas iNDVI is based on a time series in the 1980s (see Methods) and so reflects actual land use. To account for this difference we used a recent land cover data base to "mask out" (Fig. 12)

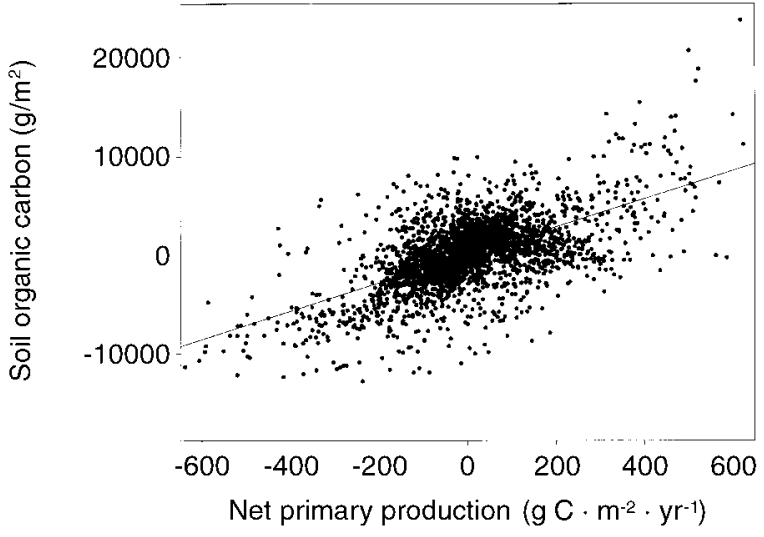

FIG. 10. Mean deviates of SOC vs. NPP for BGC. No relationship existed between the variables for Century or TEM, which are not shown.

intensively managed land cover types. We then examined iNDVI-NPP relationships for all grid cells (Fig. 13) and only for grid cells dominated by natural vegetation (data not shown). We examined both actual iNDVI and NPP and the mean deviates of NPP vs. the mean deviates of iNDVI to compare the model simulations of large-scale vs. within vegetation type variability (Fig. 13). The same analyses were also performed for mapped vs. modeled SOC and their mean deviates (Figs. 14 and 15).

The results for the continental-scale comparison of NPP vs. iNDVI show the two parameters are correlated, even without masking intensive land use regions (Fig. 13a-c), with $\mathrm{R}^{2}$ s between 0.6 and $0.7(P<0.05)$. Although the linear correlations are quite high, the relationship between NDVI and NPP is not linear and is steeper at low NPP, and less steep at high NPP (most evident in BGC and least evident in TEM). The lower NPP points are predominately grasslands and tundra. The higher points are generally forests. This indicates that forest and shrubland/savanna ecosystems can have larger changes in NPP per unit change in iNDVI than

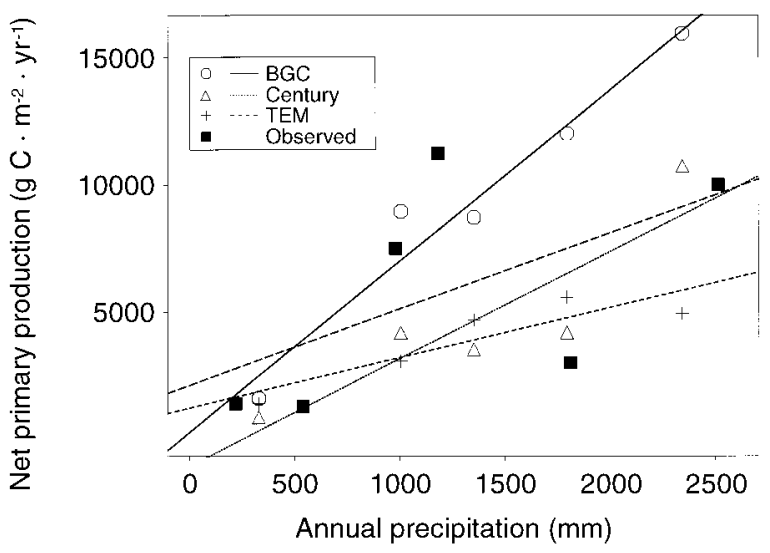

FIG. 11. NPP vs. annual precipitation: observed vs. BGC, Century, and TEM for OTTER and LTER sites. 
TABLE 3. Site-specific and corresponding gridded climate and NPP information for OTTER transect sites and Konza and CPER LTER sites.

\begin{tabular}{|c|c|c|c|c|c|c|}
\hline Field site & $\begin{array}{c}\text { Measured } \\
\text { MAP } \\
\text { (mm/yr) }\end{array}$ & $\begin{array}{l}\text { Modeled } \\
\text { MAP } \\
(\mathrm{mm} / \mathrm{yr})\end{array}$ & 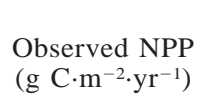 & 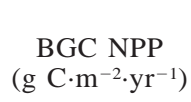 & 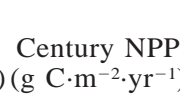 & 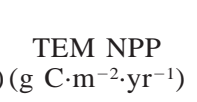 \\
\hline Cascade Head (OTTER no. 1) & 2510 & 2341 & 680 & 1593 & 1074 & 493 \\
\hline Waring's Woods (OTTER no. 2) & 980 & 1351 & 770 & 872 & 353 & 467 \\
\hline Scio (OTTER no. 3) & 1180 & 1792 & 1125 & 1202 & 419 & 557 \\
\hline Santium Pass (OTTER no. 4) & 1810 & 1004 & 375 & 896 & 418 & 305 \\
\hline Metolius (OTTER no. 5) & 540 & 330 & 160 & 161 & 86 & 140 \\
\hline Sisters (OTTER no. 6) & 220 & 330 & 150 & 161 & 86 & 140 \\
\hline CPER & 300 & 407 & $110-200$ & 105 & 99 & 253 \\
\hline Konza & 818 & 901 & $80-450$ & 415 & 543 & 408 \\
\hline
\end{tabular}

grasslands. We also recalculated the NPP-iNDVI relationships with all predominately agricultural regions masked out. Omission of the agricultural cells did not change appreciably either the form or the correlations of the relationships between iNDVI and NPP.

In contrast to the continental-scale comparison, the relationships between the mean deviates of iNDVI and NPP within vegetation type show essentially no correlation (Fig. 13d-f). The untransformed values, however, were highly correlated. This occurs in part because the absolute ranges of iNDVI and NPP within types are small relative to the continental comparisons. Land use may contribute to these differences, but when the agriculture mask was applied to the mean deviates, the correlations for all three models, low to begin with, were eliminated. The effect of land use may vary with scale because NPP, over large gradients of environmental variables, may be similar to patterns in prior natural systems (e.g., the gradient from wheat to corn within the $\mathrm{C}_{4}$ grassland region parallels the predisturbance NPP gradient from short to tall grasslands) (Schimel et al. 1990). When the vegetation types containing strong gradients (e.g., the $\mathrm{C}_{4}$ grasslands) are masked entirely or in part, the overall continental correlation declines because the remaining part of the vegetation type has little variability (e.g., the arid portion of the $\mathrm{C}_{4}$ grasslands). The relationships between iNDVI and
NPP are much stronger across vegetation types than within them, despite confounding by structural differences and radiative transfer properties between vegetation types when comparing mean deviates. Because gradients in NPP and iNDVI within vegetation types are much smaller than those across the continental domain, input data requirements for accurate simulation are more stringent at this scale.

Similar patterns of within- and between-type correlation resulted from comparison of modeled and mapped SOC. Continental-scale correlations of mapped and modeled SOC were stronger than those within vegetation types for all three models. The relationships for TEM and Century were similar (Fig. 14). BGC simulates much higher SOC in certain vegetation types than does TEM or Century. However, the models all were biased high relative to the mapped values. Taking the difference between the TEM and Century regression equations and the 1:1 relationship, the bias averages $\approx 30-40 \%$ high. Although this may reflect model bias, possibly resulting from calibration at atypically productive research sites, it probably also reflects the loss of SOC from managed ecosystems, particularly agricultural lands (Burke et al. 1989, Davidson and Ackerman 1993). Because the mapped SOC (Kern 1995) is an inventory, it reflects current conditions and the dominance of agricultural soils in the

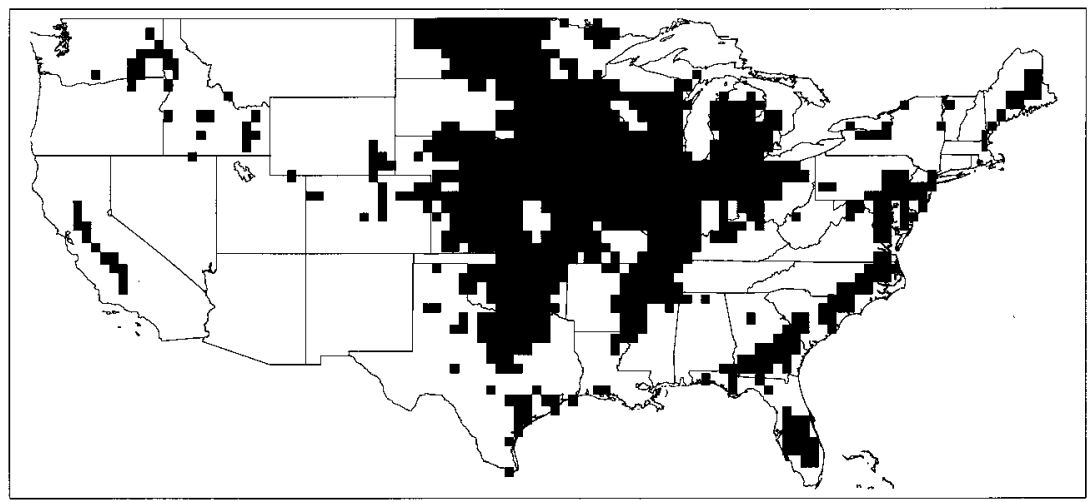

FIG. 12. The "mask" used to select cells with dominant natural vegetation for subsequent iNDVI analyses. Shaded cells have dominant agricultural or intensively managed vegetation, based on the USGS 1-km land cover map for the U.S. (Loveland et al. 1991). 

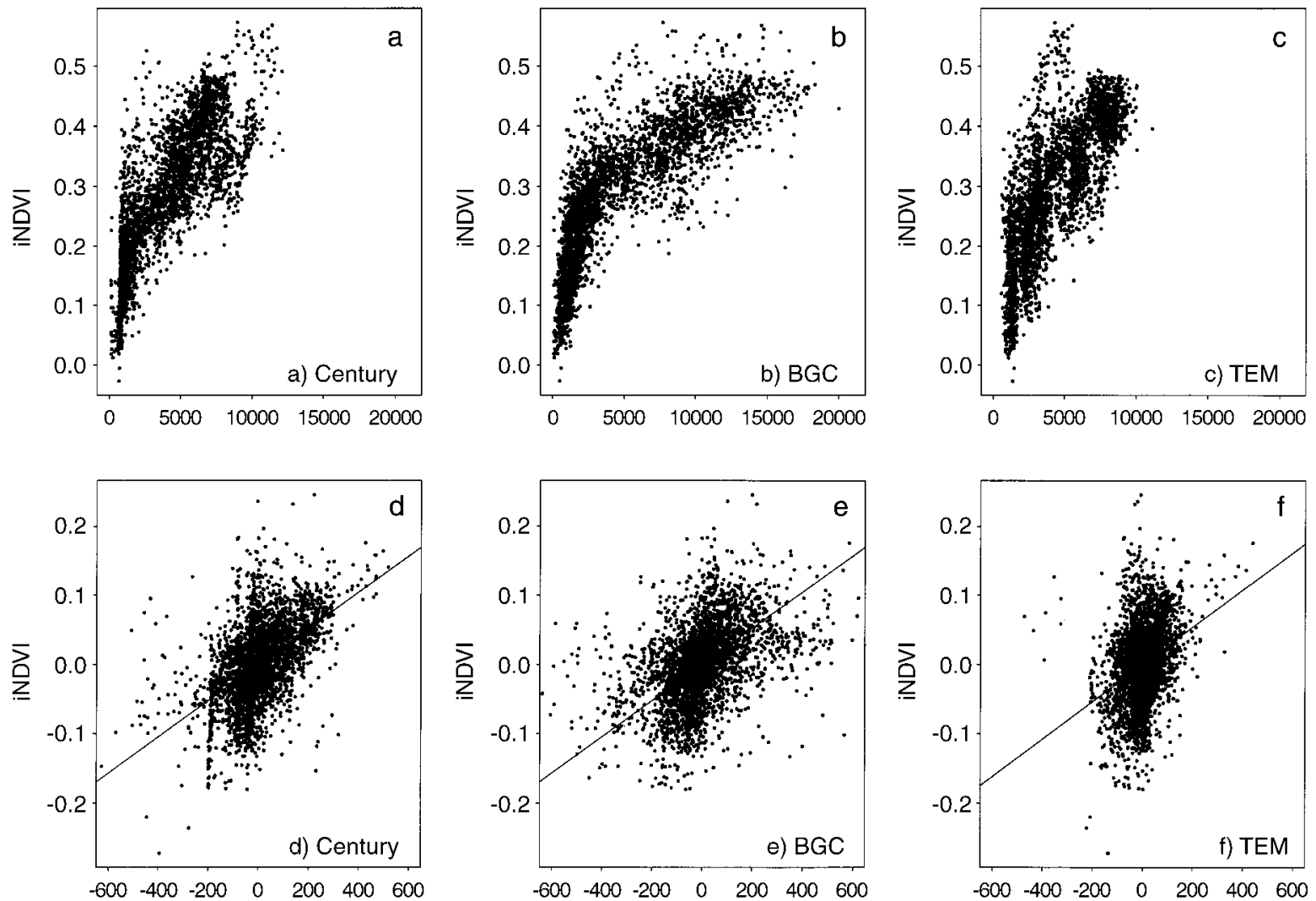

Net primary production $\left(\mathrm{g} \mathrm{C} \cdot \mathrm{m}^{-2} \cdot \mathrm{yr}^{-1}\right)$

FIG. 13. Plots show iNDVI vs. modeled NPP for all grid cells. Plots a-c show the actual values of iNDVI vs. modeled NPP for Century, BGC, and TEM, respectively. Plots $\mathrm{d}-\mathrm{f}$ show the mean deviates of iNDVI vs. the mean deviates of NPP for Century, BGC, and TEM, respectively.

NRCS data base. Also, in many forest soil profiles, the forest floor or litter layer material is excluded from SOC measurements, whereas in VEMAP surface litter and detritus, including coarse woody debris, was lumped with SOC. Inconsistency in carbon pool definition could cause a high bias in model results.

The analysis of mean deviates of SOC showed negligible correlation between mapped and modeled spatial variability in SOC within types. No trend in the relationship between the mean deviates was apparent, indicating a near-complete lack of correspondence between spatial variability in mapped and modeled SOC. This may result from many causes, including model failure, disturbance effects on soil spatial variability in SOC, and smoothing of SOC in the mapping process (Kern 1994, Kittel et al. 1995). Although TEM and Century do not simulate the spatial patterns of mapped SOC, they do reproduce the distribution of mean deviates in mapped SOC reasonably well (Fig. 15 vs. Fig. $3 d-f)$. Both models and the mapped SOC suggest that deviations in SOC within vegetation types are clustered within $\pm 2000 \mathrm{~g} / \mathrm{m}^{2}$ of the mean. The map suggests extreme mean deviates of $>+5000 \mathrm{~g} / \mathrm{m}^{2}$, reproduced closely by Century, and a cutoff just below -2000 $\mathrm{g} / \mathrm{m}^{2}$, reproduced by TEM. This suggests that the modeled relationships in Century and TEM are producing roughly the right ranges of variation in response to environmental controls. BGC simulates a broader, flatter pattern of mean deviates of SOC than either Century, TEM, or the mapped SOC.

\section{Disturbance and stand age}

In the VEMAP experimental design, stand ages for forests were assumed to be homogenous across vegetation types. Because in all three models stand age is an important, although implicit, control over carbon accumulation in biomass, the assumption of homogeneity of stand age resulted in low spatial variability in vegetation carbon. The strong relationships for all three models between vegetation carbon and NPP mean that NPP is also influenced by the assumption of stand age. From Fig. $9 \mathrm{a}-\mathrm{c}$ it is clear that if mean stand age for a given vegetation type were altered, NPP would also change in response to changing vegetation carbon, assuming that a strong correlation exists between stand age and vegetation carbon. If gradients or variability in stand age occurred within vegetation types, this 

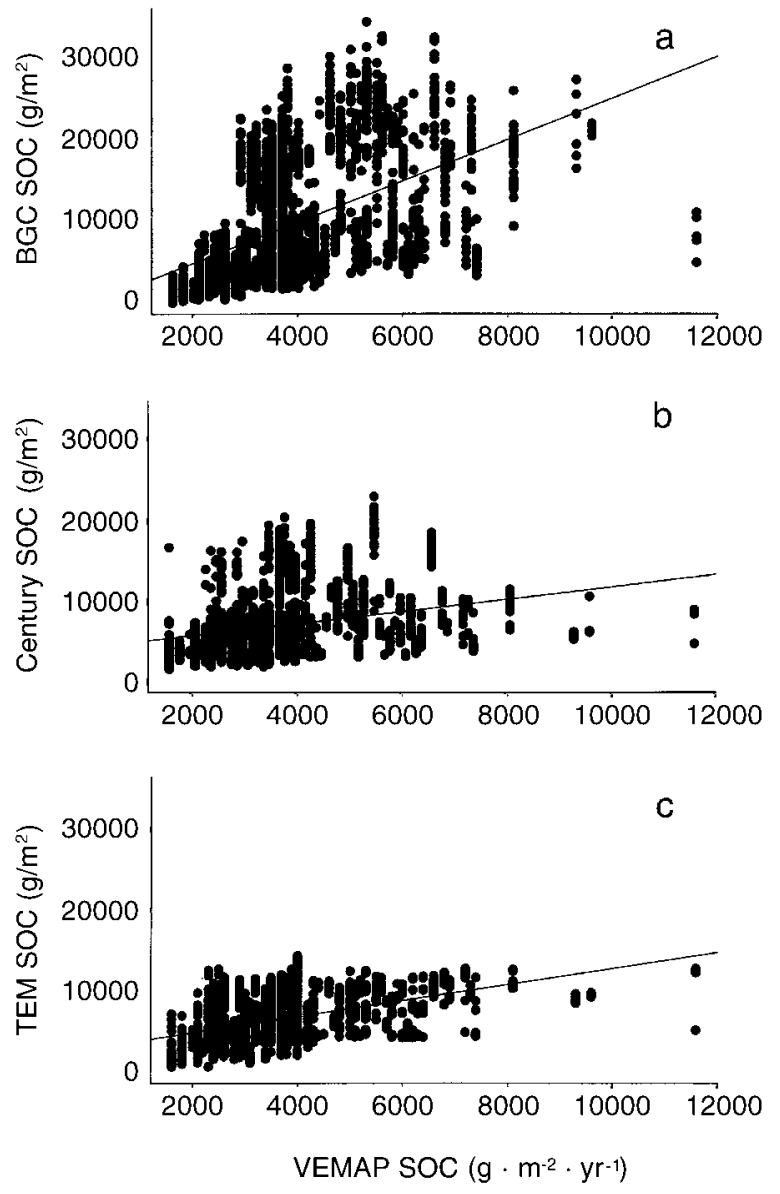

FIG. 14. Modeled vs. mapped soil organic carbon for (a) BGC, (b) Century, and (c) TEM. The agriculture mask was not applied to these data: its application does not change either the scatter or the correlation significantly.

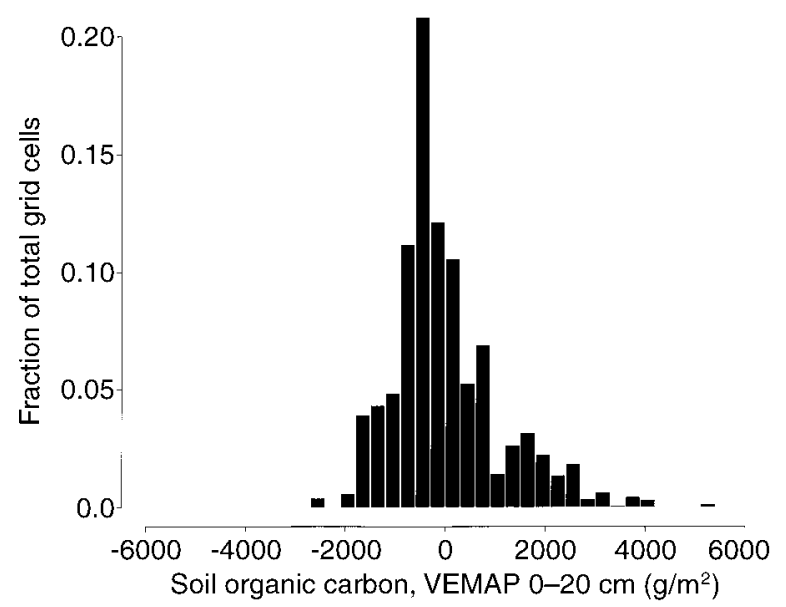

FIG. 15. Mean deviates for SOC from the mapped soil carbon data base, for comparison with mean deviates of modeled SOC shown in Fig. 3d-f. Values shown are for the areally dominant mode (mode 1) as described under Methods: Experimental protocol. would add an additional component to the simulated spatial variability of NPP.

The dependence of carbon accumulation on disturbance, population dynamics, and stand age was illustrated in a recent exercise using Century (Hibbard 1995). Hibbard (1995) used a Markov model of woody plant recruitment into a savanna-woodland ecosystem complex (VEMAP vegetation class 14) (Scanlan and Archer 1991). The Markov model determined the timing of woody plant recruitment and the areal distribution of woody plant age-states on the landscape following changes to the disturbance regime. Century simulated the accumulation of plant and soil carbon in woody and herbaceous components. As a result of both woody plant encroachment (triggered by climate, grazing, and fire suppression, specified in the Century simulations to match the drivers of the Markov model) and carbon accumulation in the woody portions of the landscape, the landscape as a whole accumulated carbon following the initiation of the fire-grazing management scheme. Simulated plant carbon in 1990 was 10 times that simulated for the prior grassland system, and soil carbon was 1.4 times higher. The changes in plant and soil carbon reflect both an increase in the area occupied by woody vegetation and increasing carbon storage in the biomass and soils of the woody areas over time. The experiment thus illustrates the dependency of simulated ecosystem processes on the age-state distribution assumed. This type of analysis can be performed for each of the VEMAP vegetation classes and would help define the variables needed to describe disturbance and successional regimes for large-scale biogeochemical calculations.

Although disturbance and the processes of population dynamics triggered by disturbance were not explicitly considered in the three biogeochemistry models considered in VEMAP, in contrast to, for example, LINKAGES (Pastor and Post 1986), sensitivity to these phenomena is implicit. The scale of VEMAP (and most continental-to-global models) is coarser than the actual scale at which most natural or human-induced disturbance occurs, and much larger than the scale at which plant population and competitive processes occur. However, the outcome of disturbance and population processes in the aggregate affects actual NPP and carbon storage at the $0.5 \times 0.5^{\circ}$ scale. A minimum requirement for spatial simulation of disturbance effects on biogeochemistry is a data set describing the disturbance regime (type, frequency) within vegetation types. VEMAP contains abundant clues that absence of such data compromises the simulation of spatial variability, and possibly of mean values, even when using models in which disturbance and the population and ecosystem consequences are only represented implicitly.

Model evaluations relative to mapped (SOC) and proxy (iNDVI) information also suggest that the absence of disturbance information increases the dis- 
TABLE 4. Continental-scale totals for NPP and total carbon storage (vegetation plus soils) for VEMAP models under current climate and $\mathrm{CO}_{2}$ conditions, with the potential natural vegetation shown in Fig. 1.

\begin{tabular}{lcc}
\hline \hline Model & $\begin{array}{c}\text { Annual NPP } \\
\left(10^{12} \mathrm{~g} \mathrm{C} / \mathrm{yr}\right)\end{array}$ & $\begin{array}{c}\text { Total } \\
\text { carbon storage } \\
\left(10^{15} \mathrm{~g} \mathrm{C}\right)\end{array}$ \\
\hline Biome-BGC & 3772 & 118 \\
Century & 3125 & 116 \\
TEM & 3225 & 108 \\
\hline
\end{tabular}

agreements between models and data, spatially and in the mean. The overall high bias of the models relative to mapped SOC likely reflects the effects of human disturbance, particularly conversion to agriculture, although other factors may also be involved. The muchreduced correlation between mean deviates of proxy/ mapped and modeled variables relative to the continental scale patterns may also reflect the role of disturbance and land use within vegetation types. On smaller scales, the NPP and iNDVI of managed systems will be constrained by environmental gradients but will also strongly reflect management, crop variety, and a host of other factors. Information on the frequency, areal extent, and carbon storage consequences of disturbance is a high priority for improving spatial modeling and could be used immediately in the current generation of models.

\section{Convergence of continental values}

One of the striking results of VEMAP (1995) was the convergence in the continental total values for NPP and carbon storage across the three models (under current climate and $\mathrm{CO}_{2}$ conditions). The results only differ by 8 and $17 \%$ among the three models for carbon storage and NPP, respectively (Table 4). This similarity is striking given the substantially different model formulations and the variations in sensitivity to climate and $\mathrm{CO}_{2}$ (VEMAP 1995). However, substantial differences occur at the grid cell level, visually apparent when the models are plotted against each other at grid resolution (Fig. 16a-c), although the scatter is less for computed annual evapotranspiration (Fig. 16c) than for NPP or carbon storage (Fig. 16a and b). Given the pronounced scatter when comparing model-simulated spatial variability (Fig. 5a-f), it is important to identify mechanisms causing convergence in the continental integrals (Table 4).

The VEMAP grid contains 3168 land grid cells, and so in displays like those shown in Fig. 16, substantial agreement or correlation could be concealed by substantial disagreement of a small proportion of outliers because of the large number of points overall; actual model-model $R^{2} \mathrm{~s}$ amongst NPP, total carbon storage, and ET range from 0.603-0.949. Identifying patterns of variability and underlying distributions in the VEMAP results is difficult. There are model-to-model biases caused by differences in fundamental or vegetation type-specific parameterizations; these biases can be reflected in mean differences between models, or by differences in the range of variability simulated. The three models have all been developed or calibrated using many common data sets; for example, all three groups used the CPER and Konza for grasslands and the H. J. Andrews forest for maritime coniferous forests, as well as a number of other LTER sites. Model results for grid cells where environmental conditions are similar to calibration sites tend to be similar for the three models. This is evident in the overall similarities in the maritime coniferous and $\mathrm{C}_{4}$ grassland vegetation type comparisons (Fig. 6, Table 3). Because of differences in
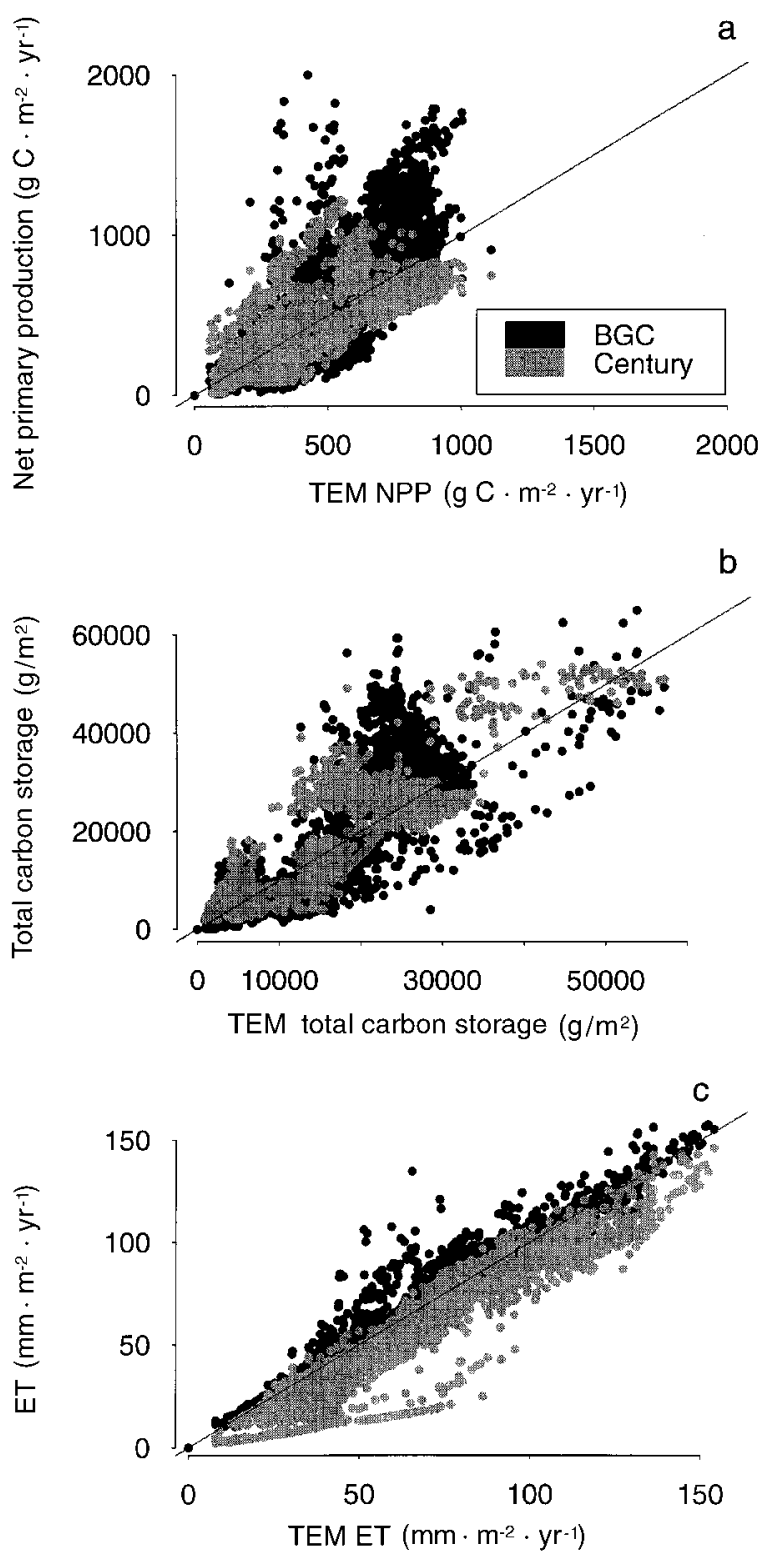

FIG. 16. (a) Plot of Century and BGC NPP vs. TEM; (b) as in (a) but for total carbon storage; (c) as in (a) but for annual evapotranspiration. 
model sensitivities to input parameters, an extreme value of, for example, soil texture, could cause one model to generate an extreme SOC, but not another model. An example of this is evident in comparing TEM's to Century's and Biome-BGC's representation of $\mathrm{C}_{4}$ grasslands, where, because of the choice of calibration data (Table 3), TEM's sensitivity to increasing precipitation is less than Century's or Biome-BGC's. This could allow agreement in the near-modal grid cells, but disagreement where values vary greatly from the vegetation class mean, resulting in different spatial patterns in the tails of the distributions of NPP or other variables.

\section{CONCLUSIONS}

The models employed in VEMAP simulated spatial variability in ecosystem processes in substantially different ways, with many of the differences resulting from each model's distinct implementation of physical vs. biogeochemical limitation of NPP. There were also differences in the simulation of soil carbon storage. The evaluation of each model's simulation of withintype spatial variability shed considerable light on their distinctive responses to environmental change, illuminating the role of climatic vs. biogeochemical controls. This substitution of space-for-time (Pickett 1988) within spatial model simulations is a useful check on steady-state model behavior (Schimel et al. 1990, 1994). In all three models, water and nutrient controls of NPP become correlated at steady state, which in Century occurs because the water budget strongly influences both the carbon and nitrogen cycles, whereas production is jointly limited by water and nitrogen availability. This is an important insight into model behavior, and is consistent with a significant body of observations (Zak et al. 1994, Schimel et al. 1996).

The convergence of continental totals likely results from calibration against overlapping sets of field sites, and the resulting simulation of similar values in sites with environmental conditions approximating the calibration sites. Differences in sensitivity and spatial variability within vegetation types, however, are reflected in the three models' substantially different simulations of climate change and doubled $\mathrm{CO}_{2}$ effects (VEMAP 1995). Modeled spatial variability and climate sensitivity within vegetation types provided more insight into the models' responses to perturbation than did examination of spatially aggregated responses (VEMAP 1995).

Although traditional model evaluation against sitespecific measurements is crucial, successful site-specific validation does not guarantee faithful simulation of spatial variability. The use of comprehensive spatial data sets is a crucial component of assessing simulated spatial variability, even when the use of comprehensive information requires the use of extrapolated or proxy data. Note that agreement at specific sites in the maritime coniferous and $\mathrm{C}_{4}$ grassland types was better than would be predicted from the distributions of mean deviates for those types. Proxy and mapped inventory data are crucial. Comparison of model results with mapped SOC and the integral of the vegetation index (iNDVI) showed the models to have substantially higher correlations across vegetation types compared to within vegetation types. This difference does not result in a simple fashion from land use effects on iNDVI, which, when masked, left the continental-scale correlations unaltered but actually reduced the within-type correlations. Detailed site-specific data of the type presented for the OTTER and LTER study sites is crucial for advancing beyond detection of model failure to model improvement, because these types of intensive data provide the information needed to better understand underlying processes.

All of the VEMAP ecosystem models are sensitive, implicitly or explicitly, to disturbance and to subsequent population responses in their simulation of NPP and carbon storage. Both the effects of disturbance (human and natural) and spatial data describing disturbance regimes are critical aspects of spatial modeling of ecosystems. Improved consideration of disturbance responses is a key "next step" for spatial ecosystem models.

\section{ACKNOWLEDGMENTS}

Data analysis reported in this paper was supported by the NASA EOS program, through an Interdisciplinary Award to David S. Schimel. Access to Pathfinder AVHRR was likewise provided through NASA. VEMAP is supported by EPRI, NASA's Mission to Planet Earth Program, and by the U.S. Forest Service. Additional support for VEMAP came from the Climate System Modeling Program of UCAR, supported by the National Science Foundation. The authors also gratefully acknowledge Elizabeth Sulzman's assistance with site data synthesis. The National Center for Atmospheric Research is sponsored by the National Science Foundation. Climate, soil, and vegetation data and climate change scenarios are available through the WorldWide Web: http.// www.cgd.ucar.edu:80/vemap/. The Pathfinder land data set is available from http://daac.gsfc.nasa.gov/CAMPAIGN_DOCS/FTP_SITE/readmes/pal.html/.

\section{Literature Cited}

Asrar, G., M. Fuchs, E. T. Kanemasu, and J. L. Hatfield. 1984. Estimating absorbed photosynthetic radiation and leaf area index from spectral reflectance in wheat. Agronomy Journal 76:300-306.

Bloom, A. J., F. S. Chapin III, and H. A. Mooney. 1985. Resource limitation in plants-an economic analogy. Annual Review of Ecology and Systematics 16:363-393.

Burke, I. C., T. G. F. Kittel, W. K. Lauenroth, P. Snook, C. M. Yonker, and W. J. Parton. 1991. Regional analysis of the central Great Plains. BioScience 41:685-692.

Burke, I. C., and W. K. Lauenroth. 1993. What do LTER results mean? Extrapolating from site to region and decade to century. Ecological Modelling 67:19-35.

Burke, I. C., C. M. Yonker, W. J. Parton, C. V. Cole, K. Flach, and D. S. Schimel. 1989. Texture, climate, and cultivation effects on soil organic matter content in U.S. grassland soils. Soil Science Society of America Journal 53:800-805.

Chapin, F. S., III, A. J. Bloom, C. B. Field, and R. H. Waring. 1987. Plant responses to multiple environmental factors. BioScience 37:49-57. 
Christie, E. K., and J. K. Detling. 1982. Analysis of interference between $\mathrm{C}_{3}$ and $\mathrm{C}_{4}$ grasses in relation to temperature and soil nitrogen supply. Ecology 63:1277-1284.

Daly, C., R. P. Neilson, and D. L. Phillips. 1994. A statistical-topographical model for mapping climatological precipitation over mountainous terrain. Journal of Applied Meteorology 33:140-158.

Davidson, E. A., and I. L. Ackerman. 1993. Changes in soil carbon inventories following cultivation of previously untilled soils. Biogeochemistry 20:161-193.

Eddy, A. 1987. Interpolated daily surface data: 1881-1985. Oklahoma Climatological Survey. NCAR dataset DS508.0.

Ehleringer, J. R., and C. B. Field, editors. 1993. Scaling physiological processes leaf to globe. Academic Press, San Diego, California, USA.

Eisele, K. A., D. S. Schimel, L. A. Kapustka, and W. J. Parton. 1989. Effects of available $P$ and $N: P$ ratios on non-symbiotic dinitrogen fixation in tallgrass prairie soils. Oecologia (Berlin) 79:471-474.

Esser, G. 1986. The carbon budget of the biosphere-structure and preliminary results of the Osnabruck Biosphere Model. Ver offentlichungender Naturforschenden Gesellschaft in Emden von 1814 7:1-160.

Farqhuar, G. D., S. Von Caemmerer, and J. A. Berry. 1980. A biochemical model of photosynthetic $\mathrm{CO}_{2}$ assimilation in leaves of $\mathrm{C}_{3}$ species. Planta 149:78-90.

Field, C. B. 1991. Ecological scaling of carbon gain to stress and resource availability. Pages 35-65 in H. A. Mooney, W. E. Winner, and E. J. Pell, editors. Response of plants to multiple stresses. Academic Press, San Diego, California, USA.

Fung, I. Y., C. J. Tucker, and K. C. Prentice. 1987. Application of advanced very high resolution radiometer to study atmosphere-biosphere exchange of $\mathrm{CO}_{2}$. Journal of Geophysical Research 92:2999-3015.

Goward, S. N., B. Markham, D. G. Dye, W. Dulaney, and J. Yang. 1991. Normalized difference vegetation index measurements from the Advanced Very High Resolution Radiometer. Remote Sensing of Environment 35:257-277.

Goward, S. N., C. J. Tucker, and D. G. Dye. 1985. North American vegetation patterns observed with the NOAA-7 advanced very high resolution radiometer. Vegetatio 64:314.

Hibbard, K. 1995. Landscape patterns of carbon and nitrogen dynamics in a subtropical savanna: observations and models. Dissertation. Department of Rangeland Ecology and Mangement, Texas A\&M University, College Station, Texas, USA

Holdridge, L. R. 1967. Life zone ecology. Tropical Science Center, San Jose, Costa Rica.

Holland, E. A., W. J. Parton, J. K. Detling, and D. L. Coppock. 1992. Physiological responses of plant populations to herbivory and their consequences for ecosystem nutrient flow. American Naturalist 140:685-706.

Ingestad, T., and A. B. Lund. 1986. Theory and technique for steady state mineral nutrition and growth of plants. Scandinavian Journal of Forest Research 1:439-453.

Kern, J. S. 1994. Spatial patterns of soil organic carbon in the contiguous United States. Soil Science Society of America Journal 58:439-455.

1995. Geographic patterns of soil water-holding capacity in the contiguous United States. Soil Science Society of America Journal 59:1126-1133.

Kittel, T. G. F., N. A. Rosenbloom, T. H. Painter, D. S. Schimel, and VEMAP Modeling Participants. 1995. The VEMAP integrated database for modeling United States ecosystem/vegetation sensitivity to climate change. Journal of Biogeography 22:857-862.

Küchler, A. W. 1964. Manual to accompany the map, potential natural vegetation of the coterminous United States.
Second edition. Special Publication Number 36. American Geographical Society, New York, New York, USA

Law, B. E., and R. H. Waring. 1994. Combining remote sensing and climatic data to estimate net primary production across Oregon. Ecological Applications 4:717-728.

Lieth, H. 1972. Modelling the primary productivity of the world. Nature and Resources 8:5-10.

Loveland, T. R., J. W. Merchant, D. O. Ohlen, and J. F. Brown. 1991. Development of a land-cover characteristics database for the conterminous U.S. Photogrammetric Engineering and Remote Sensing 57:1453-1463.

McGuire, A. D., L. A. Joyce, D. W. Kicklighter, J. M. Melillo, G. Esser, and C. J. Vorosmarty. 1993. Productivity response of climax temperate forests to elevated temperature and carbon dioxide: A North American comparison between two global models. Climatic Change 24:287-310.

Melillo, J. M., R. J. Naiman, J. D. Aber, and A. E. Linkins. 1984. Factors controlling mass loss and nitrogen dynamics of plant litter decaying in northern streams. Bulletin of Marine Science 35:341-356.

Milchunas, D. G., and W. K. Lauenroth. 1992. Carbon dynamics and estimates of primary production by harvest, ${ }^{14} \mathrm{C}$ dilution, and ${ }^{14} \mathrm{C}$ turnover. Ecology 73:593-607.

NCDC. 1992. 1961-1990 monthly station normals tape. National Climatic Data Center, U.S. Department of Commerce, data tape TD 9641.

Nobel, P. S. 1991. Physicochemical and environmental plant physiology. Academic Press, San Diego, California, USA.

Parton, W. J., D. S. Ojima, C. V. Cole, and D. S. Schimel. 1994. A general model for soil organic matter dynamics: sensitivity to litter chemistry, texture and management. Pages 147-167 in Quantitative modeling of soil forming processes. Soil Science Society of America, Madison, Wisconsin, USA.

Parton, W. J., D. S. Schimel, C. V. Cole, and D. S. Ojima. 1987. Analysis of factors controlling soil organic matter levels in Great Plains grasslands. Soil Science Society of America Journal 51:1173-1179.

Pastor, J., and W. M. Post. 1986. Influence of climate, soil moisture and succession on forest carbon and nitrogen cycles. Biogeochemistry 2:3-27.

Pickett, S. T. A. 1988. Space-for-time substitution as an alternative to long-term studies. Pages 110-135 in G. E. Likens, editor. Long-term studies in ecology: approaches and alternatives. Springer-Verlag, New York, New York, USA.

Potter, C. S., J. T. Randerson, C. B. Field, P. A. Matson, P. M. Vitousek, H. A. Mooney, and S. A. Klooster. 1993. Terrestrial ecosystem production: a process model based on global satellite and surface data. Global Biogeochemical Cycles 7:811-841

Richardson, C. W., and D. A. Wright. 1984. WGEN: a model for generating daily weather variables. U.S. Department of Agriculture, Agricultural Research Service, ARS-8.

Running, S. W. 1994. Testing forest-BGC ecosystem process simulations across a climatic gradient in Oregon. Ecological Applications 4:238-247.

Running, S. W., and E. R. Hunt, Jr. 1993. Generalization of a forest ecosystem model for other biomes, BIOME-BGC, and an application for global-scale models. Pages 141-158 in J. R. Ehleringer and C. B. Field, editors. Scaling physiological processes: leaf to globe. Academic Press, San Diego, California, USA

Running, S. W., and R. R. Nemani. 1991. Regional hydrolic and carbon balance responses of forests resulting from potential climate change. Climatic Change 19:349-368.

Runyon, J., R. H. Waring, S. N. Goward, and J. M. Welles. 1994. Environmental limits on net primary production and light-use efficiency across the Oregon Transect. Ecological Applications 4:226-237.

Sala, O. E., W. J. Parton, L. A. Joyce, and W. K. Lauenroth. 
1988. Primary production of the central grasslands region of the United States: spatial pattern and major controls. Ecology 69:40-45.

Scanlan, J. C., and S. Archer. 1991. Simulated dynamics of succession in a North American subtropical Prosopis savanna. Journal of Vegetation Science 2:625-634.

Schimel, D. S., B. H. Braswell Jr., E. A. Holland, R. McKeown, D. S. Ojima, T. H. Painter, W. J. Parton, and A. R. Townsend. 1994. Climatic, edaphic, and biotic controls over carbon and turnover of carbon in soils. Global Biogeochemical Cycles 8:279-293.

Schimel, D. S., B. H. Braswell, R. McKeown, D. S. Ojima, W. J. Parton, and W. Pulliam. 1996. Climate and nitrogen controls on the geography and time scales of terrestria biogeochemical cycling. Global Biogeochemical Cycles 10:677-692.

Schimel, D. S., T. G. F. Kittel, and W. J. Parton. 1991. Terrestrial biogeochemical cycles: Global interactions with atmosphere and hydrology. Tellus 43AB:188-203.

Schimel, D. S., W. J. Parton, T. G. F. Kittel, D. S. Ojima, and C. V. Cole. 1990. Grassland biogeochemistry: links to atmospheric processes. Climatic Change 17:13-25.

Schimel, D. S., and C. S. Potter. 1995. Process modelling and spatial extrapolation. Pages 358-383 in P. A. Matson and R. C. Harriss, editors. Biogenic trace gases: measuring emissions from soil and water. Blackwell Science, Cambridge, Massachusetts, USA.

Schimel, D. S., M. A. Stillwell, and R. G. Woodmansee. 1985. Biogeochemistry of C, N, and P in a soil catena of the shortgrass steppe. Ecology 66:276-282.
Sellers, P. J. 1985. Canopy reflectance, photosynthesis and transpiration. International Journal of Remote Sensing 6: 1335-1372.

Thornley, J. H. M. 1972. A balanced quantitative model for root:shoot ratios in vegetative plants. Annals of Botany 36: 419-430.

Tilman, D. 1985. The resource-ratio hypothesis of plant succession. American Naturalist 125:827-852.

Tucker, C. J. 1979. Red and photographic infrared linear combinations for monitoring vegetation. Remote Sensing of Environment 8:127-150.

Tucker, C. J., I. Y. Fung, C. D. Keeling, and R. H. Gammon. 1986. Relationship between atmospheric $\mathrm{CO}_{2}$ variations and a satellite-derived vegetation index. Nature 319:195199.

VEMAP Participants. 1995. Vegetation/Ecosystem modeling and analysis project (VEMAP): comparing biogeography and biogeochemistry models in a continental-scale study of terrestrial ecosystem responses to climate change and $\mathrm{CO}_{2}$ doubling. Global Biogeochemical Cycles 9:407-438.

Wedin, D. A., and D. Tilman. 1990. Species effects on nitrogen cycling: a test with perennial grasses. Oecologia (Berlin) 84:433-441.

Whittaker, R. H. 1975. Communities and ecosystems. MacMillan, New York, New York, USA.

Zak, D. R., D. Tilman, R. R. Parmenter, C. W. Rice, F. M Fisher, J. Vose, D. Milchunas, and C. W. Martin. 1994. Plant production and soil microorganisms in late-successional ecosystems: a continental-scale study. Ecology 75: 2333-2347. 